\title{
The Design of Staged Contracting
}

\author{
Albert Choi and George Triantis*
}

This Draft: November 6, 2017

\begin{abstract}
In negotiating complex business transactions, parties decide whether, when and how to invite legal enforcement of the rules that govern their relationships, particularly in their use of midstream agreements that reflect some agreement on a number of provisions but contemplate further negotiation (variously labeled memorandum of understanding, agreement in principle, letter of intent, term sheet). Under the common law of most U.S. jurisdictions, the parties have an intermediate option between enforcement and no-enforcement of such midstream agreements: a duty to bargain or negotiate in good faith or with best efforts. Law firms warn their clients about the risk of inadvertently bringing on this type of legal enforcement, but with care, this risk is small. Rather, the parties are often unclear about the freedom they prefer for themselves or their counterparties to deviate from the terms of their midstream agreements. They expect these terms to be sticky to some degree, but do not think through how much and by what means to achieve this. Judges and commentators identify the protection of specific investments as the principal goal of the commitment to bargain or negotiate. We suggest, however, that the benefit of the flexible standard of good faith or best efforts comes more broadly from mid-stream regulation of the negotiation process. Once parties have searched for and chosen their respective contracting partner, they need the incentives and flexibility to tailor and optimize the terms of their deal, while also efficiently constraining value-claiming behavior and allocating exogenous risks during their negotiations. Building on our earlier work on strategic ambiguity, we also show that concerns about the uncertainty of a flexible legal standard can be addressed.
\end{abstract}

\footnotetext{
*University of Virginia Law School and Stanford Law School, respectively. We thank workshop participants at Columbia and Stanford law schools, and particularly Patrick Bolton, Richard Craswell, Elisabeth de Fontenay, Cathy Hwang, Dan Ho, Michael Klausner, Edward Morrison, and Robert Scott, for their helpful comments and suggestions. We also thank Matthew Agnew and Berin Senne (Stanford Class of 2019) for valuable research assistance. Comments are welcome to albert.choi@virginia.edu and gtriantis@law.stanford.edu.
} 


\section{Introduction}

Contract formation in commercial transactions can be a time-consuming and complex process involving multiple stages and players, and significant investments in expertise and information. In the design of the process, parties who have decided to transact with each other face a core decision of whether - how much and in what respects - to invite legal enforcement of the rules that govern their relationships, and when to do so. Complex commercial negotiations are typically sequenced, with a subset of issues being addressed at each stage and by numerous agents with different expertise. The parties frequently enter into midstream agreements 1 labeled memoranda of understanding, agreement in principle, letter of intent, term sheet - that reflect some agreement on a number of provisions but contemplate further negotiation of remaining terms, as well as subsequent approvals and formalization of their contract. An important part of designing the negotiation agenda should be the determination of the nature and degree of legal enforcement at this midstream stage. This question seems essential to the broader decision as to why and how to divide the negotiations into stages.

Commercial actors often do not think through this part of the negotiation agenda, and consequently (consciously or not) leave it to the courts to determine ex post the degree and nature of enforcement that they implicitly intended or would have intended had they thought about it. Rather than give negotiating parties clear default rules to accept or opt out of, the law remains vague and in flux, even in the business-savvy jurisdictions of New York and Delaware. ${ }^{2}$ Law firm client letters and surveys of commercial parties reflect confusion about the legal significance of midstream agreements. ${ }^{3}$ Unless parties explicitly address the impact of their midstream agreement, one of them might face a risk of legal sanction for failure to complete their negotiations. Law firms warn their clients about this risk and caution them to express clearly their intentions. With care, the legal risk can be minimized. Yet, it appears that the parties are often unclear about the freedom they prefer for themselves or their counterparties to deviate from the terms of their midstream agreements. They expect these terms to be sticky to some degree, but often do not think through how much and by what means to achieve this.

If a court finds that the parties intended to create a binding contract irrespective of further negotiations, then the court would likely fill in the gaps that the parties left for future negotiation with legal default provisions and award the usual measure of expectation damages. This is especially true if the type of the transaction is relatively common and the terms are relatively standard. Short of full enforcement, a court may find instead that the parties promised each other to continue bargaining or negotiating up to some standard, such as good faith or best efforts, and most jurisdictions enforce this promise. The parties may have expressly agreed to do so in their midstream agreement or the court may otherwise find manifestations of such intent in the language of the document and surrounding context. This raises three fundamental questions at this intermediate level of enforcement. First, how do the courts find the requisite intent for a

\footnotetext{
${ }^{1}$ We use the phrase "midstream agreement" instead of "preliminary agreement" in order to indicate that they occur after some negotiation has occurred and also to remain agnostic about the legal treatment of these agreements.

${ }^{2}$ Infra, note --.

${ }^{3}$ Certain "midstream" agreements, such as exclusivity and confidentiality agreements used in mergers and acquisitions transactions, are expressly stated to be fully binding on the parties. See, e.g., ABA MODEL CONFIDENTIALITY AND EXCLUSIVITY AGREEMENTS. Infra note - and accompanying text.
} 
good faith duty to negotiate, including the weight they give to the presence or absence of an express promise? Second, what constitutes bad faith when negotiations break down? What effort or investment in negotiations is expected from each party? Does one party's insistence on terms that deviate from the midstream document's provisions constitute acting in bad faith? When do changed circumstances or new information justify a party from terminating negotiations? Third, what is the appropriate remedy for the breach of the good faith duty? Reliance damages are the common remedy, but some courts are willing to grant injunctive relief and expectation damages in appropriate circumstances. ${ }^{4}$

As with most contract law doctrines, the judicial approach begins with the search for manifestations of the parties' intent. Given that intent is often unclear, it is worthwhile to identify and examine the factors that guide parties in the sequencing of negotiations, their memorialization of earlier stages, the constraints they choose to impose on later stages and the means by which those constraints will be enforced. Important scholarly contributions have been made to understand this process in the fields of economics, law, and negotiation, as well as by courts and practitioners, and we seek to build on them. There is a broad consensus on several points. First, the staging of negotiations is often necessary because of the complexity of the transactions. For complex merger or finance transactions, for instance, it is practically impossible for the parties to execute a fully binding contract in a single meeting or over a very short period of time. Second, a mid-stream memorialization of agreed-upon terms is valuable because it offers protection for the investments that parties make in the process that could leave them vulnerable to opportunistic hold-up in subsequent stages of negotiation. Third, this protection comes, to a significant degree, from non-legal constraints such as moral suasion, relational and reputational sanctions. Fourth, there is general consensus that parties should be able to opt into legal regulation of their negotiation through contracts to negotiate in good faith or with best efforts. ${ }^{5}$ The law invites the parties to contract for judicial enforcement, and it is desirable to give them an option of a middle-ground between no enforcement and full contract enforcement. Legal scholarship has identified a variety of legal approaches that could protect the specific investments of the parties: from a simple implied promise to pay the reasonable reliance to a more complicated standard governing negotiations. ${ }^{6}$

This essay introduces and describes other factors that motivate midstream agreements. We suggest that this agreement is a tool for regulating the negotiation process when parties, following search and diligence activity, are reasonably confident that they have found the partner with whom they wish to deal. In these circumstances, they may seek to regulate their negotiations in one or more of the following four respects. First, as recognized in the existing

\footnotetext{
${ }^{4}$ These courts generally require that the plaintiff show that an agreement would have been reached if the defendant had bargained in good faith and provide sufficient evidence as to the terms that would have been agreed to. See, e.g., SIGA Technologies, Inc. v. PharmAthene, Inc., 132 A.3d 1108 (Del. 2015); Venture Assocs. Corp. v. Zenith Data Sys. Corp., 96 F.3d 275 (7th Cir. 1996) (Ill. law); Teachers Ins. \& Annuity Assoc. of Am. v. Butler, 626 F. Supp. 1229 (SDNY 1986); Teachers Ins. \& Annuity Assoc. v. Omesa Geothermal, 791 F. Supp. 401 (SDNY 1991). ${ }^{5}$ See, e.g., E. Allan Farnsworth, Precontractual Liability and Preliminary Agreements: Fair Dealing and Failed Negotiations, 87 Colum. L. Rev. 217 (1987); Charles L. Knapp, Enforcing the Contract to Bargain, 44 N.Y.U.L.Rev. 673 (1969) (arguing in favor of a duty to bargain in order to protect reliance); and Leon E. Trakman \& Kunal Sharma, The Binding Force of Agreements to Negotiate in Good Faith, 73 Cambridge L.J. 598 (2014) (criticizing English courts' reluctance to enforce agreements to negotiate in good faith).

${ }^{6}$ See infra notes - and accompanying text.
} 
literature, they seek to encourage specific investment in the contemplated transaction, including the design of the remaining deal terms (warranties, termination rights, remedies, and so on) that will maximize the surplus. The midstream agreement can protect such investment from opportunistic hold-up by the noninvesting party through an obligation to bargain in good faith, as well as other promises such as confidentiality, cooperation in diligence activity and exclusivity. Second, the parties would wish to discourage attempts by either side to improve its bargaining position and thereby claim a larger share of the transaction surplus. The parties have a common interest to encourage investment that creates value and discourage investment that diverts value from one party to the other. It is noteworthy in this respect that express promises to negotiate in good faith or with best efforts, are often seen in agreements side-by-side with more explicit exclusivity promises not to shop an offer or negotiate with any other prospective party for a specified duration of time. Third, the midstream agreement can also be a mechanism by which the parties can efficiently allocate selected risks of changed circumstances that would affect the distribution of surplus from the deal. Although time may be needed to complete the terms of the contract, it may be valuable for the parties to allocate some risks sooner. An example is a loan commitment that pegs the interest rate while the parties negotiate other terms of the debt such as representations, warranties and covenants. ${ }^{7}$ Fourth, while the risk of opportunistic hold-up might deter a party from making specific investment in identifying the surplus-maximizing deal terms (for example, optimal warranties), such investment might give that party beneficial private information. The investing party could use its acquired information to extract a larger share of the surplus - for example, by offering a warranty at a higher price. Anticipating this asymmetry, the uninformed party has the incentive to reject with some frequency the offer of the informed party (even if it is in fact a surplus-increasing one) and this in turn discourages that party from making the investment in the first place.

We argue that a contextual contract standard - whether good faith or best efforts - is well-suited to address this multi-faceted regulation of the negotiation process that parties often wish to invoke. Instead of the polar regimes of full enforcement or no enforcement of a preliminary agreement, an intermediate regime that obligates the parties to negotiate in good faith will help the parties to better achieve their contractual objectives, such as reliance, flexibility, policing opportunistic (rent-seeking) behavior, and risk allocation. Properly structured and construed, the duty to negotiate in good faith or with best efforts can provide incentive to the parties to undertake reliance investment that creates value while minimizing the incentive to engage in surplus extraction. Drawing from prior work in which we explain how parties can exploit the benefits of standards and avoid the potential costs of litigation and judicial error, we respond to the concerns of lawyers and scholars about the litigation of vague standards. ${ }^{8}$

The paper is organized as follows. Part I summarizes the relevant common law and judicial policy. As applied by the courts, good faith in negotiations is a standard that is focused on protecting specific investments and imposes a duty of fidelity to the terms settled in the midstream agreement. Aside of these general observations, there is a widely held view that the

\footnotetext{
${ }^{7}$ See infra note - and accompanying text.

${ }^{8}$ Albert Choi and George Triantis, Completing Contracts in the Shadow of Costly Verification, 37 J. Legal Stud. 503 (2008); and Albert Choi and George Triantis, Strategic Vagueness in Contract Design: The Case of Corporate Acquisitions, 119 Yale L.J. 848 (2010).
} 
judicial approach remains uneven and sometimes incoherent. Part II provides guidelines for the parties' design of staged contracting, as well as their use of formal midstream agreements to give some degree of stability to the terms settled in the early stage and regulate the remainder of their negotiation process. In particular, we describe the common scenario described above: after investing in search, the parties have determined that they wish to transact with each other and seek to invest in the design of optimal transaction terms while deterring value-claiming investments, and to allocate certain risks that would affect the surplus division. Part III describes the benefit of legal standards such as good faith or best efforts to support the parties' objectives in staged negotiations. The use of standards that are costly to verify and susceptible to judicial error is often dismissed in legal scholarship in favor of crisp and clear rules. We have rebutted this belief in other work and draw on that work here to show how in some circumstances, a legal standard may yield superior results to alternative approaches, whether full enforcement, lowlevel sanctions or no-enforcement. Finally, the Appendix provides a numerical example to demonstrate how a standard like good faith can promote efficient investment in the discovery of optimal contract terms when the investing party might otherwise exploit its informational advantage to appropriate rather than build surplus.

\section{The Modern Law of Preliminary Agreements}

The modern law in most U.S. jurisdictions is based on a taxonomy of three types of incomplete agreements. The first is an agreement to agree which reflects an insufficient meeting of the minds and is not legally enforceable. ${ }^{9}$ The second is an agreement with open terms to which the parties intend to be bound, even if the parties contemplate an unrealized formalization of the agreement. ${ }^{10}$ This agreement (sometimes called a type I preliminary agreement) is enforceable and the courts will fill in the missing terms, even price. ${ }^{11}$ The third is a contract to negotiate (which is alternatively referred to as a contract to bargain or a type II preliminary agreement) in which the parties agree to a course of conduct during negotiations, usually by invoking a standard such as good faith or best (or reasonable) efforts. ${ }^{12}$ In addressing these

\footnotetext{
${ }^{9}$ See, e.g., Keystone Land \& Dev. Co. v. Xerox Corp., 94 P. 3d 945 (2004)(holding that agreement to agree is nonenforceable and that "the parties did not exchange promises to conform to a specific course of conduct during negotiations, such as negotiating in good faith, exclusively with each other, or for a specified period of time"); Burbach Broad Co. of Del. v. Elkins Radio Corp., 278 F.3d 401, 408-9 (4 ${ }^{\text {th }}$ Cir. 2002).

${ }^{10}$ Restatement (Second) of Contracts \$27.

${ }^{11}$ See, e.g., Lippert v. Windsortech, Inc., 865 A.2d 1282 (Del. Ch. 2004); Vacold LLC v. Ceramic, 545 F. 3d 114 (2d Cir. 2008)(finding that the parties had addressed relevant contingencies such as buyer financing, and had a Type I contract); Learning Annex Holdings, LLC, v. Whitney Educ. Grp., Inc., 765 F. Supp. 2d 403, 410 (SDNY 2011); Cohen v. Lehman Bros. Bank, 273 F. Supp. 2d 524, 528 (SDNY 2003); Vsoske v. Barwick, 404 F.2d 495 (2d Cir. 1968); Berg Agency v. Sleepworld-Willingboro, 136 N.J. Super. 369 (1975); Larwin-Southern California v. JGB Ent., 101 Cal. App. 3d 626 (1979); Arnold Palmer Golf Co. v. Fuqua Industries, Inc., 541 F. 2d 584 (6th Cir. 1978). If there are open terms, the court can fill the gaps, even significant ones like price. See, e.g., Uniform Commercial Code $\$ 2-305$.

${ }^{12}$ The Type II label originated in the Second Circuit. Teachers Ins. \& Annuity Assoc. of Am. v. Tribune Co., $670 \mathrm{~F}$. Supp. 491 (S.D.N.Y. 1987); Arcadian Phosphate, Inc., v. Arcadian Corp., 884 F. 2 d 69 (2d Cir. 1989); Adjustrite Systems, Inc., v. GAB Business Services, Inc., 145 F.3d 543 (2d Cir. 1998). More recently, the Second Circuit described Type II agreements as follows: "Type II preliminary agreements are binding only to a certain degree, reflecting agreement on certain major terms, but leaving other terms for future negotiations. Type II agreements do not commit the parties to their ultimate contractual objective but rather to the obligation to negotiate in good faith in an attempt to reach the objective within the agreed framework." Brown v. Cara, 420 F.3d 148, 153 (2d Cir. 2005)(applying NY law, citing and quoting Tribune and Adjustrite). See Frazier Industries, LLC v. General
} 
midstream agreements — whether labelled as MOUs, LOIs, term sheets, or agreements in principle - courts and scholars have gravitated to the middle ground between full and no contract enforcement. ${ }^{13}$ Most have converged on a duty to negotiate in good faith ${ }^{14}$ but, in contrast to some civil law jurisdictions, this duty must be found in the objective intent of the parties to be bound rather than being triggered simply by the start of negotiations. ${ }^{15}$ Allan Farnsworth explained the policy behind the absence of wholesale regulation of negotiation in the U.S. as follows:

The difficulty of determining a point in the negotiations at which the obligation of fair dealing arises would create uncertainty. An obligation of fair dealing might have an undesirable chilling effect, discouraging parties from entering into negotiations if chances of success were slight. The obligation might also have an undesirable accelerating effect, increasing the pressure on parties to bring negotiations to a final if hasty conclusion. ${ }^{16}$

These downsides — chilling and acceleration — are avoided when the parties themselves choose to invite the court to police their negotiations. ${ }^{17}$

Most courts are inclined to enforce clear and express language agreeing to or disclaiming good faith duty. ${ }^{18}$ But, sometimes the language of the parties' midstream agreement is

Fasteners Co., 137 Fed. App. 723 (6 $6^{\text {th }}$ Cir. 2005). Meanwhile, IDT Corp. v. Tyco Grp., S.A.R.L., 13 N.Y. 3 d 209 (2009)(although critical of the Type I/Type II distinction, the court found a binding obligation to negotiate in good faith, but not a breach). See, generally, Farnsworth, supra note --, at 253, 263.

${ }^{13}$ This has been a movement in the U.S. away from the historical common law position that agreements to agree are not binding. Ridgeway v. Wharton, 10 Eng. Rep. 1287 (House of Lords 1857) is a classic statement that agreement to agree is not enforceable. For decades contract scholars have been calling for middle ground with good faith standard. E.g., Knapp, supra note --; Farnsworth, supra note --.

${ }^{14}$ E.g., Teachers Ins. v. Tribune Co., supra note --; Brown v. Cara, supra note --; Venture Assocs. v. Zenith Data supra note -- ; Newharbor Partners v. F.D. Rich Co., 961 F.2d 294 (1 ${ }^{\text {st }}$ Cir. 1992)(Rhode Island); Channel Home Ctrs. V. Grossman, 795 F.2d 291 (3d Cir. 1986)(Pa law); Copeland v. Baskin Robbins, 117 Cal. Rptr. 2 d 875 (Cal. Ct. App. 2002); SIGA Technologies, Inc., v. PharmAthene, Inc., 132 A. 3d 1108 (Del. 2015); Logan v. D.W. Sivers Co., 169 P.3d 1255 (Or. 2007) (en banc). It seems that fewer than a dozen have yet to enforce agreements to negotiate. [List here]

15 The good faith and fair dealing in the UCC and Restatement Second does not extend to pre-contract negotiations. See infra note - and accompanying text. See Teachers Ins. v. Tribune, supra note - ("prime significance attaches to the intentions of the parties and to their manifestations of intent")

${ }^{16}$ E. Allan Farnsworth, CONTRACTS (4th Ed. 2004) \$3.26 at 199.

${ }^{17}$ Under the Uniform Commercial Code, an enforceable contract modification requires not only mutual assent but also good faith which, between merchants, includes observance of reasonable commercial standards of fair dealing in the trade. U.C.C. 2-209, ct 2. Although new consideration is no longer necessary to support an enforceable contract modification, "modifications...must meet the test of good faith imposed by this Act [the Uniform Commercial Code $§ 1-304 ; 2-103(b)] " . ~ § 2-209$ c2. "The effective use of bad faith to escape performance on the original contract terms is barred, and the extortion of a 'modification' without legitimate commercial reason is ineffective as a violation of the duty of good faith. Nor can a mere technical consideration support a modification made in bad faith" Id. The common law rule, as reflected in section 89 of the Restatement (Second) of Contracts requires either fresh consideration or that the modification be fair and equitable in view of circumstances not anticipated by the parties when the contract was made. Restatement (Second) of Contracts $\S 89(a)$.

${ }^{18}$ See, e.g., Emma Robinson, Getting Out of a Bind: Making Sure Your Non-Binding Letter of Intent is Actually Non-Binding, Weil Insights, Weil Global Private Equity Watch, March 24, 20016 (stating that clear and unambiguous statements will be enforced). See Newharbor Partners v. F.D.Rich Co., 961 F. 2d 294, 298-9 (1st Cir. 
ambiguous or rendered ambiguous by other indicators, and courts may look more broadly at relevant evidence, including: (a) the parties' intent as revealed in the language of the agreement; (b) the context of the negotiations; (c) the existence of open terms or lack of clarity, particularly essential, material or major terms; (d) the conduct of the parties, including partial performance; and (e) the customary use of formalities in this type of transaction. ${ }^{19}$ Even if the parties express their intent to have no binding obligations, extrinsic statements (including internal communications within one party's organization) or conduct may lead the fact finder to hold that the parties intended to have good faith duty. Given the highly fact-dependent nature of the inquiry and the immaturity of the good-faith doctrine in this area, commentators have noted that the case law is characterized by inconsistent results and lawyers warn clients about the consequent traps for the unwary in letters of intent and similar documents.

Although courts are no strangers to standards of good faith or best efforts, commentators have noted that the content of this standard remains difficult to specify and predict. ${ }^{20} \mathrm{~A}$ review of the case law suggests that the central factor is fidelity to the terms settled in the midstream agreement. For example, in Teachers Ins. \& Annuity Assoc. of Am. v. Tribune Co. (S.D.N.Y. 1987), Judge Leval stated that "parties can bind themselves to a concededly incomplete agreement in the sense that they accept a mutual commitment to negotiate together in good faith in an effort to reach final agreement within the scope that has been settled in the preliminary agreement."(italics added) ${ }^{21}$ Under this agreement, a party may demand that its counterparty "negotiate the open terms in good faith toward a final contract incorporating the agreed terms." (italics added) ${ }^{22} \quad$ Judge Leval further stated that "each [party] was obligated to seek in good faith to conclude a final agreement within the terms specified in the commitment letter, supplemented by such representations, warranties and other conditions as are customary in such transactions. Teachers would not have been free to walk away from the loan by reason of a subsequent decision that the transaction was not in Teachers' interest." (italics added) ${ }^{23}$ In Brown v. Cara, the Second Circuit described it as an "obligation to negotiate the open issues in good faith in an attempt to reach the [contractual] objective within the agreed framework." 24 Similarly, in Adjustrite Systems, Inc., v. GAB Business Services, Inc., the Second Circuit held that a party did not negotiate in good faith when it "insisted on conditions that do not conform to

\footnotetext{
1992)(the enforceability of obligation to act in good faith "turns on the clarity with which such intent is expressed in the instrument").

${ }^{19}$ See, e.g., Teachers' Ins. \& Annuity, supra note -- at --; Brown v. Cara, supra note - at 157; Learning Annex, supra note --, at 411; Arcadian Phosphates v. Arcadian, supra note - at 72.

${ }^{20}$ E.g., E. Allan Farnsworth, Precontractual Liability and Preliminary Agreements: Fair Dealing and Failed Negotiations, 87 Colum. L. Rev. 217, 259-60 (1987) ("[i]t would be difficult to find a less predictable area of contract law"); Ronald J. Gilson, Charles F. Sabel and Robert E. Scott, Braiding: The Interaction of Formal and Informal Contracting in Theory, Practice and Doctrine, 110 Colum. L. Rev. 1377, 1427 (2010)(“the courts' experience so far provides little normative guidance concerning the breadth of the enforceable obligation"); Alan Schwartz and Robert E. Scott, Precontractual Liability and Preliminary Agreements, 120 Harv. L. Rev. 661, 675 (2007) ("This modern approach provides too little normative guidance.")

${ }^{21}$ Supra note --, at 498 . The court also stated that "the obligation to negotiate in good faith prevents a party from ... insisting on conditions that do not conform to the preliminary agreement". Id. See A/S Apothehernes Laboratorium for Specialpraeparata v. I.M.C. Chem. Group, 873 F.2d 155, 159 (1989)(obligation to negotiate in good faith "can only be determined from the framework the parties have established for themselves in the letter of intent."

${ }^{22}$ Id.

${ }^{23}$ Teachers Insurance v. Tribune, supra note - at 500-01.

${ }^{24}$ Brown v. Cara, supra note --, at 153.
} 
the preliminary writing". ${ }^{25}$ This is especially true if the condition was important and could have reasonably been included in the midstream document. Similar holdings existed in a number of other cases. $^{26}$ In the high-profile case of SIGA v. Pharmathene, the court held that the licensor, "SIGA[,] failed to negotiate in good faith for a definitive license agreement in accordance with the terms of the LATS [term sheet]." Midstream agreements often reflect the parties' intention to limit the freedom of the parties to depart from terms settled therein and the courts are willing to enforce this intent in their application of the good faith (or best efforts) standard. ${ }^{27}$

As stated in many federal and state court opinions, the predominant policy goal of the duty to bargain and fidelity to the terms of the preliminary agreement, is to protect and encourage efficient transaction-specific investments and minimize the risk of opportunistic holdup behavior. An example is the statement in a recent First Circuit opinion that "modern transactions often involve significant up-front investments in deal structuring and due diligence and parties may wish to protect those investments in some measure...without such protection, a rapacious counter-party may attempt to take advantage of the other party's sunk investment by trying to retool the deal at the last minute." 28 Indeed, some courts suggest that judicial enforcement of a contract to negotiate is unlikely — even in the face of bad faith — in the absence

\footnotetext{
${ }^{25}$ Adjustrite, supra note --, at 48. See also EQT Infrastructure Ltd. v. Lawrence Smith (SDNY 2012)(on motion to dismiss complaint, court held that the insistence on a condition that was not provided in letter of intent - that the seller find a buyer for another asset -- can indicate absence of good faith).

${ }^{26}$ Itek Corp. v. Chicago Aerial Indus. Inc. is perhaps the opinion that initiated the trend toward judicial enforcement of contracts to negotiate. 248 A.2d 625 (Del. 1968 applying Ill. law). In that case, the letter of intent stated that parties "shall make every reasonable effort to agree upon and have prepared as quickly as possible a contract providing for the foregoing purchase...embodying the above terms and such other terms and conditions as the parties shall agree upon." Id., at 627. A third party bid higher and the seller terminated negotiations even though the buyer agreed to all additional terms proposed by the seller, including price adjustments and other concessions. See also Shann v. Dunk, 84 F.3d at 77-8 (2d Cir. 1996)(“all important terms were settled and the parties agreed to negotiate in good faith over any differences that might arise relating to the undrafted boilerplate")(italics added); EQT Infrastructure v. Smith, supra note -- (the condition that the seller find a buyer for related assets could not be introduced later if the term sheet did not include it).

${ }^{27}$ After the release of the Delaware Supreme Court's opinion in SIGA, supra note --, lawyers at Fried Frank wrote "[ $\mathrm{t}]$ he obligation of good faith would be breached by abandonment of negotiations, insistence on terms materially inconsistent with the LOI; breach would be more likely if there is evidence of regret, and less likely if there is a material disagreement over a term not in the LOI" Andrew J. Colosimo et. al., Practice Points for Term Sheets, Letters of Intent, and Undertakings to Negotiate in Good Faith-Based on Delaware Supreme Court's SIGA Decision, Fried Frank Private Equity Briefing (Feb. 8, 2016), available at: http://www.friedfrank.com/siteFiles/Publications/FINALv8-2-8-2016-

Practice $\% 20$ Points $\% 20$ on\%20Use $\% 20$ of $\% 20$ Term\%20Sheets\%20and \%20Letters\%20of\%20Intent.pdf. Lawyers at Lincoln Gustafson wrote that the good faith obligation would be breached by "attempt[s] to change fundamental points of the deal in order to take advantage of changing external conditions and extract more favorable terms than were initially agreed upon in the letter of intent." Patrick Klingborg, When a "Non-Binding" Letter of Intent Is Binding After All, Lincoln Gustafson \& Cercos, LLP (Jun. 1, 2016), available at: http://www.lgclawoffice.com/when-a-non-binding-letter-of-intent-is-binding-after-all/.

${ }^{28}$ E.g., Butler v. Balolia, 736 F.3d 609 (1st Cir. 2013). See Burbach Broadcasting Co. of Del. v. Elkins Radio Corp., supra note -- ("many state courts have recognized the pragmatism and commercial necessity of recognizing such agreements"); Venture Assoc. v. Zenith Data, supra note--, at 279-80 (seller could demand a higher price "provided that it was not trying to scuttle the deal... or take advantage of costs sunk by Venture in the negotiating process"); Brown v. Cara, supra note --; Copeland v. Baskin Robbins, supra note --.
} 
of significant reliance in between the contracting stages; these are likely to be treated as mere agreements to agree. ${ }^{29}$

Nevertheless, there are divergent opinions about the role of legal enforcement in promoting reliance. Contrast, for example, the opinions of two judges who are also contract law scholars, Judge Posner and Judge Easterbrook. In justifying legal enforcement, Judge Posner wrote:

[S] uppose the prospective buyer spends $\$ 100,000$ on research, planning and consultants during the negotiation, money that will have bought nothing of value if the negotiation falls through, while the seller has spent nothing and at the end of the negotiations demands an extra $\$ 50,000$, threatening to cancel the deal unless the buyer consents. ${ }^{30}$

In contrast, Judge Easterbrook held in another case that:

"Empro [the buyer of business assets] claims that it is entitled at least to recover its 'reliance expenditures,' but the only expenditures it has identified are those normally associated with pre-contractual efforts...negotiating with defendants, in investigating and reviewing defendants' business, and in preparing to acquire defendants' business'. Outlays of this sort cannot bind the other side any more than paying an expert to tell you whether the painting at the auction is a genuine Rembrandt compels the auctioneer to accept your bid". ${ }^{11}$

The contrast between these opinions suggests that it there may not be a uniform approach to protecting all types of investment and that the parties may prefer more contextual regulation. We return to two facets of this contrast in the analysis in Part II, as we also broaden the possible objectives of the good faith obligation.

Given that the protection of specific investment motivates the arguments in favor of contracts to negotiate, reliance is the usual measure. ${ }^{32}$ Significantly, however, a number of opinions have indicated that expectation damages may be appropriate if the plaintiff provides evidence that good faith efforts would have led to an agreement and if the terms of that hypothetical agreement are clear enough that such damages could be calculated. ${ }^{33}$ As we discuss in the next part, the openness to expectation damages may reflect a recognition that parties use

${ }^{29}$ E.g., Burbach Broadcasting Co. of Del. v. Elkins Radio-Corp., supra note --; Skycom v. Telstar, 813 F.2d 810 (7th Cir. 1987)(raising concern about making transactions riskier without need to protect reliance).

${ }^{30}$ Venture Associates Corp., supra note - at 278.

${ }^{31}$ Empro Manufacturing Co., Inc. v. Ball-Co Manufacturing, Inc., 870 F.2d 423, 426 (7 ${ }^{\text {th }}$ Cir. 1989).

${ }^{32}$ Farnsworth, CONTRACTS, supra note --, at --. [add cases here]

${ }^{33}$ E.g., Venture Associates Corp., supra note - at 278 ("if the plaintiff can prove that had it not been for the defendant's bad faith the parties would have made a final contract, then the loss of the benefit of the contract is a consequence of the defendant's bad faith, and, provided that it is a foreseeable consequence, the defendant is liable for that loss - liable, that is, for the plaintiff's consequential damages."). See also United House of Prayer for All People v. Therrien Waddell, Inc, 112 A.3d 330 (D.C. 2015)(expectation damages appropriate if trial court finds that a contract would have been concluded if the defendant had acted in good faith and that there is a basis for calculating lost profits); SIGA Technologies, Inc. v. PharmAthene, Inc.; Teachers Insurance v. Butler... [add expectation damages cases] 
midstream agreements to pursue objectives other than the protection of specific investment, including the allocation of some risks.

\section{Designing Staged Contracting}

Two challenges face commercial parties in designing staged contracting. The first is whether a court will accurately find manifest intent to create or disclaim a contract to negotiate in good faith (or with best efforts). This challenge is the focus of lawyers' advice to clients, but the easier of the two, especially given that the commercially sophisticated parties can create or disclaim such a duty through an express agreement. The second challenge is that the parties should determine what effect they wish to assign to their midstream agreement or the agreement to negotiate. In many cases, the parties give this second question insufficient consideration, and they are often confused or of two minds. They may simply want to get the best of both worlds by binding their counterparty while preserving their own freedom to walk. Or, they would like some mutual constraint, but are unsure about how much and how to combine legal with nonlegal means to achieve it.

\section{A. Why and How to Sequence Negotiations}

The negotiation agenda, including the sequencing of issues, can affect the deal outcome and indeed, may be the subject of bargaining over process. ${ }^{34}$ In many cases, negotiations are sequenced and a subset of issues is addressed at each stage. If nothing else, sequencing is a response to cognitive barriers to negotiating all issues at once. There is a tradeoff between the benefit of being able to logroll across issues to exploit differences in preferences and endowments, and the cognitive load of doing so. ${ }^{35}$ When deals are broken up into manageable parts, how the issues are divided and sequences is a distinct and important question. One approach is that of gradualism or incrementalism, under which easier issues are settled first in order to build trust and a positive atmosphere, to create momentum to face the more difficult issues in subsequent stages. ${ }^{36}$ The terms that are more difficult to resolve are more likely to be the major terms that, in turn, courts are more likely to require in an enforceable contract to negotiate. ${ }^{37}$

\footnotetext{
${ }^{34}$ Game theorists have shown that the decision to negotiate issues simultaneously or sequentially is likely to effect the probability of success and the negotiated outcome. See, e.g., Thomas C. Schelling, THE STRATEGY OF CONFLICT 31 (1960); Chaim Fershtman, The Importance of the Agenda in Bargaining, 2 Games \& Econ. Behav. 224 (1990); Younghwan In and Roberto Serrano, Agenda Restrictions in Multi-issue Bargaining, 53 J. Econ. Behav. \& Org. 385 (2004); P.V. Balakrishnan, Charles Patton, Phillip A. Lewis, Toward a Theory of Agenda Setting in Negotiations; Mehmet Bac and Horst Raff, Issue-by-Issue Negotiations: The Role of Information and Time Preference (1996) (noting, for example, that the American Automobile Association recommends buyers focus first on negotiating price of the car and defer discussing of financing, factory rebates, and the trade-in-allowance). ${ }^{35}$ Howard Raiffa, NEGOTIATION ANALYSIS: THE SCIENCE AND ART OF COLLABORATIVE DECISION MAKING -- (2002).

${ }^{36}$ This is a common approach in international negotiations or agreements in legislative law making [add cites]. It is less common but nevertheless occurs in business transactions as well. See Ben-Shahar, "Agreeing to Disagree", supra note --, at 390 ("leaving issues that were difficult to resolve for future completion. In these situations, contractual incompleteness is neither a result of haste nor of unforeseeability, but rather a deliberate choice to temporarily disagree over some matters, to side-step difficult issues over which consensus could not be reached.")

${ }^{37}$ Supra note - and accompanying text.
} 
An alternative strategy moves in the opposite direction, tackling first the potential roadblocks associated with essential terms before time is spent on the easier matters. This seems to be more common sequence in business transactions. Together with early diligence, agreement to the main deal terms - particularly price -- help to ensure and signal that the parties are confident they have found the right partner. The benefit of this sequencing is reinforced by the need for costly lawyers, accountants, architects and other experts. It makes sense to have the essential elements of the bargain reflect the prospect of a profitable transaction before these investments are incurred. Although the first stage addresses the major terms - such as what is being sold and at what price- the second stage is not trivial. Even if the second stage consists of lawyers hammering out representations and warranties, covenants, closing conditions, remedies and termination rights, these can contribute significant value to the transaction. ${ }^{38}$

The sequencing of the monetary price of a transaction is particularly interesting, especially to the degree that it is difficult to revise a settled price because of the enforcement discussed below. ${ }^{39}$ Price is a unique deal term in two important respects. First, it is likely to be the most divisible consideration in a contract: it can be adjusted by dollars while a quality measure cannot. Second, it is typically the distributional term in the contract with the least impact on the size of the aggregate contracting surplus. Although price is often set after the nonprice terms have been set, this is not always the case. For example, in commercial loans, private equity investments, and corporate acquisitions, many terms are agreed upon after the price is settled: representations and warranties, covenants, termination rights, choice of law and forum, and so on. ${ }^{40}$ In the first stage of negotiations, the parties agree to price and key non-price provisions, often without their lawyers, and then turn over the second stage to their lawyers to work out these contractual details. These terms, though valuable, are usually settled without adjustment to price. This arrangement leads to a peculiar process in the second bargaining stage between lawyers in which the parties are limited to bartering non-price provisions. ${ }^{41}$ Thus, the stickiness of price constrains the ability of the parties to maximize the efficiency of their contract design, particularly when the parties are not using standard or market terms. ${ }^{42}$ Yet, as explained below in Section II.C, there are countervailing efficiency advantages from agreeing to distributional parameters and allocating some risks, while working toward maximizing the contracting surplus.

\footnotetext{
${ }^{38}$ Although the value that lawyers contribute is difficult to quantify, the fact that they can command significant hourly rates for work performed after midstream documents suggests that the market values their contributions to contracts in the second stage. [add cites]

${ }^{39}$ See Albert Choi and George Triantis, The Effect of Bargaining Power on Contract Design, 98 Va. L. Rev. 1665 , 1690-6 (2012).

${ }^{40}$ See., e.g., James C. Freund, ANATOMY OF A MERGER: STRATEGIES AND TECHNIQUES FOR NEGOTIATING CORPORATE ACQUISITIONS 53-60 (1975).

${ }^{41}$ It is interesting in this respect to contrast two types of debt contracts that settle price early or late in the process. In a typical commercial bank loan, the parties first negotiate a term sheet that contains the maturity, interest rate and other fees, in addition to a handful of major terms. The interest rate is rarely changed subsequently during the negotiation of the covenants, etc. In contrast, in the sale of a bond or debenture, the covenants are settled before the price is determined. Given the advantages of the price term and constraints on nonprice bartering identified in the text, one might speculate that, all else equal, the design of bond covenants would be more efficient. One might also anticipate more innovation in the provisions of non-bank debt, where the market can reward valuable contract terms with a lower yield.

${ }^{42}$ Moreover, it is generally perceived that the second round presents the opportunity for the party with the bargaining power to seize more rents because the price cannot be reopened. See Choi and Triantis, Bargaining Power on Contract Design, supra note --.
} 


\section{B. Purpose of Midstream Document}

Parties to complex transactions are likely to engage in back-and-forth proposals of deal terms and, at some point, to memorialize the settled terms for the benefit of future negotiations and communications with internal and external constituencies. One view held by deal lawyers is that midstream agreements are "signposts - they mark a moment in the deal's lifecycle when enough uncertainty and complexity has been resolved that the deal is likely to go forward... [They are] markers for the accumulation of deal momentum."43 According to this view, these documents are not legally binding and instead, they indicate that momentum has been achieved and a completed deal is in prospect along the lines of the thereto settled terms. The parties use this information as a sign that they can proceed to incur negotiation costs. ${ }^{44}$ Indeed, these midstream documents serve as evidence and information to the deal team of lawyers, accountants, and other advisers, as well as lenders, investors and other third parties who will contribute to the project. ${ }^{45}$ In this respect, commentators sometimes refer to these midstream documents as mechanisms for "organizing" these third parties. ${ }^{46}$ Of course, the signal of momentum is not a particularly reliable one in the economic sense, because it is relatively cheap (or even costless) to send unless there is some sanction, legal or nonlegal, on the party that deviates from the terms of the agreement, thereby rendering them "sticky" to some degree.

Given that flexibility is needed for the parties to design the optimal terms of exchange, the optimal stickiness is both a matter of degree and of type. Moreover, the protection of specific investments is but one goal that the parties may seek when regulating their negotiation process. As we elaborate in the next section, when the parties conclude their search for the right partner, they then agree to basic terms that crystallize, at least to some degree, the distribution of (expected) contracting surplus while they invest in designing the optimal terms of trade that will maximize the surplus. In fact, the imposition of a duty to bargain in good faith may provide a useful costly signal of each party's confidence that they have searched and found the appropriate counterparty. ${ }^{47}$ The parties may also use the midstream agreement to protect the surplus distribution against certain risks. We describe these goals in the next section. The obligation to negotiate in good faith may be provided for in combination with other express terms that the parties intend to be legally binding. In particular, as the parties continue their diligence investigation after the midstream agreement, the party being investigated may promise to

\footnotetext{
${ }^{43}$ Cathy Hwang, Deal Momentum, 65 U.C.L.A. L. Rev. (forthcoming). See also Alan P.W. Konevsky, A U.S. perspective on the risks of term sheets, Butterworths Journal of International Banking and Financial Law 353-6 (June 2011) available at https://www.sullcrom.com/siteFiles/Publications/Konevsky_JIBFL_June_2011.pdf. ${ }^{44}$ See, e.g., ABA MODEL PURCHASE AGREEMENT WITH COMMENTARY, v 2, 107 (2001) ("to test the waters for the prospects of a definitive agreement before incurring the costs of negotiating a definitive agreement"). ${ }^{45}$ Included in these third parties are regulators whose approvals are condition precedent to the closing of the deals and who need the time to review (e.g. antitrust review). See ABA MODEL ASSET PURCHASE AGREEMENT, v. 2. at 107. Regarding the agency problems associated with having lawyers and other experts negotiate the second stage, see Albert Choi and George Triantis, Multi-stage contracting in complex transactions (working paper February 2014).

${ }^{46}$ See Ralph B. Lake, Letters of intent: A Comparative Examination under English, U.S., French and West German Law, 18 Geo. Wash. J. Int'l L. \& Econ. 331, 332 (1984)(“bringing order to complexity"); ABA MODEL ASSET PURCHASE AGREEMENT, v. 2. at 107; Hwang, supra note --.

${ }^{47}$ See Richard Craswell, Precontractual Investigation as an Optimal Precaution Problem, 17 J. Legal Stud. 401, 403 (1988).
} 
cooperate by releasing relevant information while the investigating party may promise to keep information confidential. The parties may also agree to a period of exclusivity, during which they agree not to shop, solicit or discuss similar transaction with any third party.

\section{Stickiness of Settled Terms in Midstream Document}

When adopting a midstream document with varying degrees or types of stickiness, several different objectives, with attendant tradeoffs, become salient. In this section, we focus on four: (1) encouraging relationship-specific (or deal-specific) investment while retaining desired flexibility; (2) discouraging inefficient surplus-grabbing; (3) promoting efficient allocation of risk that may arise from changes in circumstances; and (4) addressing problems of asymmetric information and the related hazard of bargaining failure.

\section{Flexibility and Specific Investment}

Contracting parties often intend that preliminary agreements not be fully enforceable because they contemplate needing flexibility to accommodate another significant stage in negotiation. ${ }^{48}$ Given the requirements that contract law imposes even on consensual modifications to binding contracts, ${ }^{49}$ the parties have greater flexibility if they agree to negotiate in good faith from preliminary terms than if they enter into a binding contract with the view to subsequently modifying it. This flexibility is particularly important if the parties anticipate that they will acquire new information, or be subject to changed circumstances, that would either reveal efficient terms of exchange or indicate that the transaction is inefficient under any terms. Any stickiness in the initial terms - especially price terms, as noted above-limits the opportunities to logroll and agree to all efficient terms. This flexibility should not be surrendered without offsetting benefit from imposing some weight on settled terms. The protection of reliance investments is commonly cited as the countervailing goal. ${ }^{50}$

While lawyers warn their clients against agreeing inadvertently to legally binding terms in the midstream documents, ${ }^{51}$ it is clear that parties do contemplate some form of commitment. Commentators observe that parties tend not to depart from the terms in the midstream agreement and that the second stage usually leads to completed contracts. ${ }^{52}$ How the stickiness is achieved is a matter of some speculation but it is often phrased in non-legal terms. Frequently commentary suggests that parties use them to bind counterparties "morally," "psychologically," or "ethically." 53 Of course, some business entities hope to use midstream agreements to bind

\footnotetext{
${ }^{48}$ Eg., Hwang, supra note - ("most preliminary agreements in M\&A deals are signed, but specifically designated to be non-binding"). Hwang also notes that "deals are sticky even though enforcement for breach is weak"). repeat players and one-off deal parties, in private and public deals, in a variety of firms and cities, representing financing parties and strategic parties - report that preliminary agreements have exceptional binding power." Hwang, supra note --, at n.54.

${ }^{53}$ ABA MODEL ASSET PURCHASE AGREEMENT at 107 ("The parties may also feel morally, if not legally, obligated to key terms [in a letter of intent] if those terms are set down in writing"); Farnsworth, supra note -- at 258; Knapp, supra note --, at 679 (business persons consider themselves bound, if not legally, at least morally or ethically); Freund, supra note - at - ("antirenegotiation insurance"); Lena G. Goldberg and Mary Beth Findlay, Just
} 
their counterparty while retaining freedom for themselves to withdraw with impunity. ${ }^{54}$ It is also possible that the reputation of lawyers (and other agents, including financial advisers) provides the discipline discouraging the parties from walking or demanding unwarranted changes in settled terms.

Although enforcement of preliminary terms may interfere with the ex post efficiency of a negotiated deal, the decision to sequence negotiations presumably requires that the first stage terms would have to be somewhat settled before beginning the second stage. Otherwise, how would you maintain the psychological benefits of a gradual compromise or the fragmentation of complex issues? What would be the value of addressing roadblocks first if they could reappear late in the negotiations? Moreover, parties would negotiate more seriously before the midstream agreement if they knew that there would be a cost to renegotiating or walking away from its terms. At the same time, excessive stickiness would chill negotiations and defer the memorialization of negotiations. Similarly, if the purpose of the memorialization of a term sheet is to commence discussions with a lender or other third party, this purpose would be also be undermined if the parties could later change the major terms. Of course, these benefits and the ones described below would need to be weighed against the benefits of flexibility discussed above: adjusting to new information and changed circumstances and logrolling between terms across the stages.

As indicated earlier, the dominant reason usually given for (partial) enforcement of midstream agreements as contracts to negotiate is to protect and encourage specific investments that would increase the expected deal surplus or avoid an inefficient deal. ${ }^{55}$ Often, the investment contemplated by courts, scholars and lawyers, is the cost of negotiating and contracting over the terms of the deal, and the retaining of experts to advise on performance (lenders, architects, etc.). ${ }^{56}$ The classic concern of contract theory is that if price is negotiated

an MOU or a Real Deal? Harvard Business School Publishing Note 9-312-018 (2011) at p. 3 ("Unless there has been a material adverse change, it may be difficult, psychologically, to renegotiate terms that are expressly included in an MOU.)"

${ }^{54}$ See Mark K. Johnson, Enforceability of Precontractual Agreements in Illinois: The need for a middle ground, 68 Chi.-Kent L. Rev. 939, 939 (1993).

${ }^{55}$ In a short essay in the first issue of the Negotiation Journal of the Harvard Program on Negotiation, Howard Raiffa suggested a process by which parties who had entered into a negotiated settlement would jointly go to an intervenor (from the Contract Embellishment Service) who would propose an alternative that would replace the original one only if both parties would prefer it over the original. The contract with the intervenor might offer her a slice of the extra surplus she created. The intervenor would meet separately with each party and keep the content of conversations in strict confidence, in order to create incentives for honest disclosure. Howard Raiffa, PostSettlement Settlements, 1 Negotiation Journal 9 (January 1985). This paper addresses the more common version of this idea: the parties reach an agreement on the basics and then seek to increase the surplus through joint effort rather than retaining an intervenor.

56 "[W]ithout such an agreement, parties may spend enormous sums negotiating every detail of contract wording without knowledge whether they have an agreement, and if so, on what terms." Teachers' Ins. v Tribune, supra note - at 414. See also Hwang, supra note - at -- ("enforcing a preliminary agreement means that the parties can rely on their preliminary bargains as they engage in the costly process of solving for deal complexity.") In client letters, law firms advise clients to "determine whether they have a meeting of the minds on the material terms of a deal before proceeding with the more detailed, prolonged, and costly effort of definitive documentation". Fried Frank, supra note --. And, to "make sure they are on the same page as to the significant points of a deal before they undertake the time and expense to prepare a detailed contract to express their complete agreement." Lincoln Gustaffson, supra note --. 
after one party has made such reliance investment, the other party may engage in hold-up during negotiations of the price to deprive the former party of its investment. If the terms have not been settled, this hold-up hazard is unchecked and the parties may wish that the courts police it through a promise to negotiate in good faith.

A related category of investment is in diligence to assess whether deal is efficient. This investment, however, may occur before and after the midstream agreement. In fact, from a survey of counsel to merger and acquisition deals, Cathy Hwang observes that although "[s]cholars assume that preliminary agreements are first steps... before investigation and before making relationship-specific investments. In reality, parties sign preliminary agreements slightly later in the deal process, after most initial investigation is done." ${ }^{27}$ Their ability to continue conducting diligence can be enhanced in midstream agreements by binding promises to provide one's counterparty with access to records and related materials, share of expenses and adhere to non-disclosure requirements. To the extent that Hwang has identified a category of transactions in which most of the investment in search has been completed before the midstream agreement for example, an acquirer and target in a corporate transaction -- it suggests that the parties have confidence that they have selected the optimal partner and that the transaction is likely to be efficient. ${ }^{58}$ The open question is under what terms. In these cases, the significant reliance investment is in the negotiation and design of the deal terms.

In a different context, Schwartz and Scott examine incentives in "exploratory" preliminary agreements, under which the parties agree to make simultaneous investment in information that would indicate whether and which of a set of contemplated projects would be profitable to pursue. ${ }^{59}$ For example, a seller would investigate its cost of delivering a good and the buyer would investigate the value it would receive, and the parties may agree that they would then share the acquired information to determine whether the transaction is efficient. Without enforcement of the promise to invest, each party has the incentive to cheat: to let the other party invest first and decide later whether to invest. The authors believe that the good faith duty can encourage investment by ordering the reneging party to pay the reasonable costs of the performing party's preliminary investment. Scott and Schwartz remark that the predominant legal approach, via the contract to negotiate, "is deficient, however, because it is unnecessary to require the parties to bargain in good faith. As we show, efficiency would be enhanced if the law were simply to protect the promisee's reliance interest." In their analysis, they assume that the reliance expenditure is ultimately verifiable, as is its reasonableness, so the good faith standard is an unnecessarily indirect means to create the efficient investment incentive.

\section{Discouraging Inefficient Investment in Bargaining Power}

Negotiation experts contrast strategies of value-creation and value-claiming. The foregoing discussion concerns value-creation: how the parties can design their deal terms to maximize their transaction surplus. Investment leading to efficient terms is desirable in this

${ }^{57}$ Supra note --, at --. See Victor P. Goldberg, Protecting Reliance, 114 Colum. L. Rev. 1033, 1042-5 (2014)(discussing the balance in the enforcement of preliminary agreements between protection of reliance and flexibility to adapt contract terms to new information).

${ }^{58}$ See Craswell, supra note --.

${ }^{59}$ See Vladimir Smirnov \& Andrew Wait, Holdup and Sequential Specific Investments, 35 RAND J. ECON. 386 (2004). 
respect and the parties should seek to encourage such investment. Value-claiming strategies aim to capture a larger share of the surplus by changing the perceived bargaining range between the parties' reservation prices. They entail usually costly actions that yield a private return to the actor at the expense of the counterparty, yielding a net reduction in the transactional surplus. First, a party can improve its alternatives to the agreement (known as BATNA ${ }^{60}$ ), raise its reservation price and thereby improve its share of the surplus. ${ }^{61}$ It can do so by seeking and developing negotiations with alternative counterparties. To be sure, investing in alternatives can reveal a more efficient deal elsewhere; but the motivation of concern here is to improve bargaining power. Second, one party's selfish interest is served by becoming better informed about its counterparty's reservation price and changing its counterparty's perception of its own. ${ }^{62}$ Of course, the counterparty has the corresponding incentive to conceal that value. Expenditures incurred to conceal one's own or reveal one's counterparty's reservation price do not contribute to efficiency, unless they produce information relevant to whether the deal and its terms are optimal. Third, a party may take actions to hurt the counterparty's no-agreement alternative or BATNA and thereby change the bargaining range in the former party's favor.

The joint goal of deterring value-claiming investments is distinct from encouraging value-creating investments. As Schwartz and Scott point out, incentives for surplus-creating investments can be created by a simple promise to share expenses or reimburse if the deal falls through, because the party incurring the cost has the incentive to provide evidence that they were made and were reasonable. ${ }^{63}$ It is much more difficult to deter value-claiming investments because they are both difficult to observe and verify. It is not surprising, therefore, that midstream agreements often have no-shop, no-talk or other exclusivity restrictions on developing alternatives during a time set for negotiations, alongside the contract to negotiate in good faith. ${ }^{64}$ The good faith standard is broader than the specific exclusivity restrictions and the court's investigation into the good faith or best efforts of each party can police value-claiming behavior not caught by the specific prohibitions. ${ }^{65}$ For example, it is easier to verify the seller's marketing of an asset than the buyer's search for alternative acquisitions.

As an alternative to policing the value-claiming activities themselves, the parties could seek to neutralize any advantage gained after the signing of the midstream agreement, by locking in the distribution of the surplus while encouraging the parties to invest in maximizing the

\footnotetext{
${ }^{60}$ BATNA stands for: Best Alternative To a Negotiated Agreement. See Roger Fisher and William Ury, GETTING TO YES (1981).

${ }^{61}$ David A. Lax and James K. Sebenius, THE MANAGER AS NEGOTIATOR: BARGAINING FOR COOPERATION AND COMPETITIVE GAIN 55, 251-2 (1986).

${ }^{62}$ G. Richard Shell, BARGAINING FOR ADVANTAGE 104-5 (2006).

${ }^{63}$ Supra note --.

64 See, e.g., JamSports \& Entm 't, LLC v. Paradama Prods, Inc., 336 F.Supp. 2d 824 (N.D.Ill.2004)(parties agreed to negotiate "exclusively and in good faith" and to "use their best efforts, negotiating in good faith" to enter into a definitive agreement); Model Exclusivity Agreement [cite]. In some cases, the exclusivity and duty to bargain is phrased more categorically: e.g., Channel Home Centers v. Grossman, 795 F.2d 291 (3d Cir. 1986) (letter of intent covered most of the significant shopping mall lease terms and provided that the prospective lessor would "withdraw the Store from the rental market and only negotiate... the leasing transaction to completion").

${ }^{65}$ But see SuperValu Inc. v. Associated Grocers, Inc., 428 F.Supp.2d 985, 991 (D. Minn. 2006)(applying Wash. law)("A generalized duty to negotiate in good faith, as found in the language in the Letter of Intent, does not require disclosure of competing negotiations.”); Schwanbeck v. Federal-Mogul Corp., 578 N.E. 2d 789, 798-99 (1991), rev'd on other grounds, 592 N.E. 2d 1289 (1992)(same).
} 
surplus. Where this is an important goal, the parties incur the loss of some logrolling flexibility by agreeing on price terms in the midstream stage and limiting the ability of either party to demand a large revision in the price or other key terms. Each party has a correspondingly limited incentive to improve its BATNA or impair its counterparty's BATNA. The parties might allow each other to walk away from the deal but not to propose modified terms that shift the surplus-sharing proportion significantly in favor of one party or the other. Or, they may simply close off the ability to take advantage of an outside offer in any respect by adding an exclusivity clause, as in the SIGA-PharmAthene agreement described below. ${ }^{66}$

\section{Risk Allocation}

Another reason that parties may prefer stickiness in their midstream agreement terms also distinct from protecting specific investment - is to manage risks that affect the size and distribution of the deal surplus. Risk allocation is a well-known, core function of contracts. Even if a deal is not completely negotiated, allocating some risks of changes in circumstances during the negotiation period may be efficient and there may be gains to putting this allocation in place sooner rather than later. New circumstances or information can lead to (a) a change in the expected distribution of the contracting surplus, (b) a change in the expected size of the joint gains from the contemplated transaction, and (c) a change that renders the transaction inefficient. Optimally, the parties would seek to avoid the deal in the last contingency and to preserve it in the first and second contingencies, perhaps with modified or additional nonprice terms in the second. Indeed, this ex ante challenge is familiar in the design of a fully binding agreement and enforcement of contracts in the face of changed circumstances. The same principles apply to midstream agreements and the enforcement of obligations to bargain in good faith.

If the parties incorporate terms that assign such a risk, either explicitly or implicitly, the court should enforce that allocation. In this light, good faith may be breached when a party attempts to escape the adverse materialization of a risk allocated to it under the midstream agreement, by breaking off negotiations or demanding an unreasonable modification of the settled terms. ${ }^{67}$ A party breaches its good faith obligation when it unreasonably insists either on changing the settled terms, particularly if it thereby seeks to escape or modify the deal because of the materialization of a risk that was otherwise allocated to that party. ${ }^{68}$

The leading cases concerning (Type II) contracts to negotiate in good faith in the Southern District of New York concern loan commitments entered into by Teachers Insurance and Annuity Association of America (TIAA), and they provide good examples of the risk allocation function of midstream agreements. ${ }^{69}$ The commitment letters in those cases

\footnotetext{
${ }^{66}$ Supra notes - and accompanying text.

${ }^{67}$ In the contract modification context, see Varouj A. Aivazian, Michael J. Trebilcock, and Michael Penny, The Law of Contract Modifications: The Uncertain Quest for a Bench Mark of Enforceability, 22 Osgoode Hall L. J. 173 (1984).

${ }^{68}$ See, e.g., A/S Apothekernes Laboratorium for Special Paraeparater v. I.M.C. Chemical Group, Inc., 873 F. $2 \mathrm{~d}$ 155,158 ( $7^{\text {th }}$ Cir. 1989)(“For instance, a party might breach its obligation to bargain in good faith by unreasonably insisting on a condition outside the scope of the parties' preliminary agreement, especially where such insistence is a thinly disguised pretext for scotching the deal because of an unfavorable change in market conditions.")

${ }^{69}$ Teachers Ins. \& Annuity Assoc. of Am. V. Butler, 626 F. Supp. 1229 (SDNY 1986); Teachers Ins. \& Annuity Assoc. of Am. v. Tribune, supra note --; Teachers Ins. \& Annuity Assoc. v. Omesa Geothermal, 791 F. Supp. 401
} 
memorialized agreement on the basic loan terms, including the rate of interest, and left other clauses to be negotiated in the next stage: such as closing conditions, covenants, events of default, covenants, remedies, default prepayment fees. The letters stated that these other provisions would be negotiated "within the scope that has been settled in the preliminary agreement."70 The court found that the letters were Type II agreements because the parties did not intend to enter into fully binding loan agreements but sought to police negotiations by agreeing to bargain in good faith. During the negotiation of the open provisions, market interest rates fell and the borrower in each case sought to escape or renegotiate the rate of interest.

In one case, the court found that the borrower objected to the lender's proposal to include a default prepayment fee as "a pretext for not going forward with the loan," "71 instead of counteroffering or otherwise negotiating over that term. The court held that the "refusal to negotiate with respect to the Default Prepayment Fee Language was simply a last-ditch attempt to scuttle the loan agreement." 72 In a second case, the borrower insisted that the deal was conditional on its ability to report the loan in its financial statements as an off-balance-sheet offset. The court found that the borrower "unreasonably insist[ed] on a condition outside the scope of the parties' preliminary agreement, especially where such insistence is a thinly disguised pretext for scotching the deal because of an unfavorable change in market conditions."73 In the third case, the borrower argued that the lender had inappropriately insisted on call protection right outside the scope of the commitment letter, but the court held that the borrower's argument was a pretext for escaping an unfavorable interest rate. The court found that the "borrower took a negotiating stance allegedly designed to alter or scuttle the transaction and finally refused to continue negotiating with TIAA claiming that TIAA had 'walked' from the deal." 74

Significantly, the New York court in these cases suggested that TIAA be awarded expectation damages equal to the difference between the expected interest income under the contract and what it would get by lending to a third party at the time of breach. ${ }^{75}$ Although the court was clearly concerned about the lender's specific investment, ${ }^{76}$ which might have been compensated with reliance damages, its approach in the face of market change was to enforce the allocation of interest rate risk that the parties had agreed to in their commitment letter. Therefore, it held that expectation damages were appropriate despite the fact that many

(SDNY 1991). See also Titan Inv. Fund II, LP v. Freedom Mortg. Corp., 58 A. 3d 984 (Del. 2012)(change in credit market made deal unattractive but court found that defendant strung plaintiff along to buy time before escaping deal). In other cases, however, courts have found that the parties did not allocate market risks and those courts focused instead on the hazard of hold-up. See Venture Assoc. v. Zenith Data, supra note - (per Posner, J.)

${ }^{70}$ Teachers $v$. Tribune, supra note --, at 498.

${ }^{71}$ Teachers $v$. Butler, supra note --, at 1234.

${ }^{72} \mathrm{Id}$., at 1235.

${ }^{73}$ Teachers $v$. Tribune, supra note --, at 506.

${ }^{74}$ Teachers v. Omesa, supra note --, at 507 ("While in Butler the borrower breached by refusing to negotiate a clause that was within the scope of the agreed terms, here the borrower breached by refusing to negotiate unless the lender agreed to modify the deal by accepting a new condition").

${ }^{75}$ Teachers $v$. Butler, supra note --, at 1236; Teachers $v$. Omesa, supra note --, at 415.

${ }^{76}$ See Teachers $v$. Tribune, supra note --, at 499 ("without such legal recognition, parties would be obliged to expend enormous sums negotiating every detail of final contract documentation before knowing whether they have an agreement, and if so, on what terms") 
provisions were left to be negotiated (so that the letter was not a fully-enforceable Type I agreement). ${ }^{77}$

In other cases, whether and how the parties intended to allocate risks of changes in their environment is usually not as clear as in the loan commitment of the cases described above. Without such a clear indication, the court can look for evidence of such allocation in the text or circumstances of the parties' agreement or could make an educated guess as to the parties' likely intent. Whether explicit or implicit, risk allocation in commercial transactions is typically meant to promote efficiency. The basic principle underlying analogous elements of contract doctrine is that the superior risk bearer is likely to be the party who can control the probability or magnitude of the contingency or who can better insure against it. ${ }^{78}$ This principle provides useful guidance in some cases. As noted earlier, the midstream agreements often occur in the middle of diligence activity. Presumably, the risk of error in prior diligence should normally fall on the party conducting the diligence (barring some act of concealment or fault of the other party) while the risk of surprises from future diligence would not. Indeed, midstream agreements often provide explicitly for prospective diligence activity with language requiring the other party to cooperate and stating that final agreement is contingent on the report of the pertinent expert, whether engineer, accountant, architect or lawyer. ${ }^{79}$

Other risks are significantly more difficult to assess because the determination of the superior risk bearer is less clear. We have suggested that the central component of good faith in midstream agreements is fidelity to the settled midstream terms and the Delaware case of SIGA v. PharmAthene provides a good example. It also highlights the importance of objectives other than the protection of specific investments, particularly the allocation of risk. In fact, the court found that expectation damages were appropriate if the trial court found that the parties would have concluded a contract but for the defendant's bad faith. Yet, the implicit allocation enforced by the court is debatable under the facts provided in the courts' opinions. SIGA acquired an antiviral smallpox drug in 2004, but it encountered difficulties developing the drug and was running out of money by the end of 2005. Desperate for infusion of cash, it entered into discussions with PharmAthene, who was interested in either acquiring SIGA or receiving a worldwide license of the smallpox drug. While negotiating a merger, the parties signed a two-page license agreement term sheet in early 2006. They subsequently entered into a merger agreement and a contract for $\$ 3$ million in bridge financing. Under both these agreements, the parties agreed that if the merger failed to close, they would negotiate a license agreement in good faith "in accordance with" the term sheet. In fact, the merger did not close and the parties resumed negotiating the license agreement. However, SIGA had meanwhile met with considerable and unexpected success with the drug: it was awarded approximately $\$ 20$ million in new grants from the National Health Institutes and announced that the drug had provided full protection against smallpox in a trial with primate subjects. It had also sold 2 million shares of stock at a price more than three times its 2005 share price. SIGA then presented PharmAthene with an offer for

\footnotetext{
${ }^{77}$ It is true, however, that expectation damages in these cases mimic reliance damages when the opportunity cost of having lent the money elsewhere is accounted for.

${ }^{78} \mathrm{~A}$ classic example is the doctrine of commercial impracticability as explained in Richard A. Posner and Andrew M. Rosenfield, Impossibility and Related Doctrines in Contract Law: An Economic Analysis, 6 J. Legal Stud. 83 (1977).

${ }^{79}$ E.g., Larwin-Southern California v. JGB Ent., 101 Cal. App. 3d 626 (1979)(conditional on approval in engineer's report)
} 
a license agreement on terms that were radically more favorable to SIGA than the term sheet. PharmAthene brought action in the Delaware Court of Chancery, who found that SIGA acted in bad faith when it proposed these different terms. On appeal, the Supreme Court upheld, finding that:

Evidence that SIGA began experiencing 'seller's remorse' during the merger negotiations for having given up control of what was looking more and more like a multi-billion dollar drug bolsters the Vice-Chancellor's finding that SIGA failed to negotiate in good faith for a definitive license agreement in accordance with the terms of the LATS [term sheet]. ${ }^{80}$

It is noteworthy that the court sought to protect PharmAthene's inchoate expectation in the term sheet and not simply its reliance interest. The implication of the court's opinion is that a party like SIGA could not use supervening events that would improve its bargaining position, to extract better terms from PharmAthene. Cases such as this illuminate the purpose of good faith bargaining promises that goes beyond the protection of reliance investments (after all, most investments were made by SIGA), and seeks to lock-in the distribution of contracting surplus while encouraging the parties to focus on maximizing the size of the surplus by designing optimal contract terms. The court's decision also protects this distribution from the materialization of certain risks. In the SIGA case, PharmAthene's argument implicitly stated that the term sheet also conferred on it a significant share of the upside risk of the drug's effectiveness, just as it would have been under a duty to negotiate to an agreement if the drug's prospects had dimmed. Whether this risk had in fact been allocated through the provisions in the term sheet could be disputed. The parties might well have contemplated a renegotiation of the surplus distribution if the prospects improved as dramatically as they did in fact. Given that the improvement was due to SIGA's post-term-sheet efforts, it is plausible that they would have wanted to provide SIGA with a larger share of the incremental value.

\section{Rent-seeking from Private Information}

We noted in section II.1, that the parties often wish to provide incentives for investment in discovering the parameters of efficient deal terms (such as the optimal representation or warranty, or closing condition) that will increase the size of the transaction surplus, whether by reducing the seller's cost or increasing the buyer's value from the exchange. The deterrence to such investment is the threat of a hold-up: in a subsequent (re)negotiation, the noninvesting party appropriates enough of the benefit to leave the investing party with a negative return from its investment. Some stickiness in terms can protect the investing party from hold-up and thereby encourage investment. If one party has the bargaining power in the relationship, however, then it can capture the surplus and is relatively immune from hold-up even if there are no enforceable terms beforehand. ${ }^{81}$

In light of the threat of hold-up of investment in contract design, it is curious that parties in many transactions jockey to be the authors of the first draft of an agreement. There are, of

\footnotetext{
${ }^{80}$ SIGA v. PharmAthene, supra note--, at

${ }^{81}$ Albert Choi and George Triantis, The Effect of Bargaining Power in Contract Design, 98 Va. L. Rev. 1665, 1686-7 (2013)
} 
course, advantages to being the initial drafter such as the familiarity of its team with the template document and the tendency of negotiations to anchor on offered terms. There is another phenomenon that the parties may need to attend to. The investing party may obtain private information on the basis of which it might propose a new or additional deal term: especially, the value or cost of that term to the counterparty. The uninformed counterparty, however, doesn't know whether the proposed term is (a) efficient (b) random or (c) opportunistic in the sense of selling a term at a higher price than it is worth. For example, a seller may use its superior information about the value of warranties to a buyer to dupe that party into accepting a broader warranty at a higher price. ${ }^{82}$ Anticipating this rent-seeking behavior, the less informed party may rationally reject any offer of a term from the informed party, even when it may be in fact efficient. This, of course, undermines the incentive of the latter party to invest in the first place. This prospect of this equilibrium raises an obstacle to efficient contracting that the parties would want to address ex ante.

As we describe at greater length elsewhere, the inefficient consequences of such asymmetric information can affect many kinds of contract negotiations. The Appendix provides an illustration in the context of staged contracting in which the seller of a good may invest in private information as to the value and cost of alternative contract provisions. The Appendix illustrates that the hazard from asymmetric information is greater if the midstream agreement is fully binding, because a fully binding agreement provides a guarantee of the profit under the initial contract to the informed party. Even if the buyer rejects the seller's proposed alternative, the seller can enforce the initial contract. In contrast, if the midstream agreements are nonbinding, the incentive of the informed seller to dupe a buyer into a broad warranty term is partially attenuated because the seller has no enforceable contract to fall back on if the buyer balks.

A legally enforceable standard such as good faith can better address this problem by punishing a party who attempts to renegotiate the terms of the agreement solely for the purpose of extracting rent from the counter party (even though the party has reason to know that the renegotiated term will not increase -- and may in fact decrease -- the surplus from trade). By imposing duty to bargain in good faith, backed by court enforcement that is costly to obtain, the contracting parties can discourage such opportunistic behavior in the negotiation process. Moreover, when the parties are reassured that opportunistic behavior is deterred, it is easier for them to supplement or adjust the terms when they are, in fact, more efficient. This, in turn, restores the incentive of each party to invest in information relating to the choice among contract terms. The analysis shows that judicial enforcement of a duty to negotiate in good faith creates the optimal level of stickiness to promote both ex post flexibility and ex ante investment. Achieving optimal flexibility can coincide with achieving optimal investment. The numerical example in the Appendix demonstrates that, if appropriately structured, such a standard can police the better informed party's ability to extract rent from the less informed. It is therefore a

\footnotetext{
82 That one party may have superior information about the other party's valuation of contract terms is somewhat unconventional in contract theory, but the possibility is realistic. It is very plausible in consumer contracts. See, generally, Alex Tabarrok and Tyler Cowan, The End of Information Asymmetry, Cato Unbound (Spring 2015) at https://www.cato-unbound.org/2015/04/06/alex-tabarrok-tyler-cowen/end-asymmetric-information. It is also possible in commercial contexts, particularly where value and cost are correlated: having private information
} 
mechanism that the parties may choose to adopt in their regulation of the negotiation process. We discuss more generally the virtues of contract standards in the next Part.

\section{The Use of Legal Standards to Vindicate the Goals of Staged Contracting}

In this paper, we analyze moderately-binding midstream agreements as formal instruments that govern the parties' negotiation process and we identify objectives beyond the protection of specific investments. They create value by establishing parameters for negotiation to promote the following objectives discussed in the previous section: (a) encourage efficient investment, (b) preserve relative bargaining power by deterring value-claiming investment, (c) enforce the risk allocation desired by the parties during the negotiations and (d) allow flexibility to use new information and expertise to build surplus from the deal. ${ }^{83}$ It is essential that enforcement of midstream agreements be less than full, given that under full contract enforcement, the court would fill the open terms in the midstream agreement with the legal defaults and typically award expectation damages to the plaintiff. Such enforcement would not balance well the multiple goals that often motivate the parties in the midstream agreement; the optimal enforcement is something short of the full contract enforcement. While there is a broad consensus in favor of a middle-ground, there are a range of approaches suggested by legal scholar, many of which combine legal and non-legal enforcement.

At one end of the spectrum, as mentioned above, Cathy Hwang observes that the terms of midstream agreements are sticky even though enforcement by either courts or reputational sanctions is likely to be weak (or even non-existent). She suggests that lawyers may be the gatekeepers whose reputations are harmed when a party walks away from such an agreement contrary to the parties' expectations. As described in the previous Part, Alan Schwartz and Robert Scott advocate for protection of specific investment through reliance damages, particularly in the specific context they describe, in which parties commit to making simultaneous investments. Under their approach, the party who fails to make their investment must reimburse the non-breaching party's investment costs. In a subsequent article, Ronald Gilson, Charles Sabel and Robert Scott advocate for this scheme of reliance damages as "lowpowered" legal enforcement, which can combine with extralegal forces to implement the desired degree of freedom from the substantive terms of the contemplated deal. ${ }^{84}$

Jonathan Barnett describes an interesting alternative configuration of legal and extralegal discipline. He examines the context of Hollywood movie deals and suggests that parties are disciplined by a combination of industry norms and the possibility that a plaintiff would succeed in obtaining enforcement from a court. He refers to these deals as "soft contracts" that are possibly but not certainly subject to legal liability. Parties can achieve their preferred level of enforcement and, conversely, transactional flexibility by calibrating the level of formalization used to memorialize the terms, and therefore the probability that they will be legally binding. Barnett describes that "parties face a calculated tradeoff — with respect to each deal element, deal

\footnotetext{
${ }^{83}$ See Butler v. Balolia, supra note --, at - ("binding themselves sufficiently such that they feel comfortable investing resources into the deal, but without inextricably committing themselves to a transaction that is still inchoate. Contracts to negotiate can satisfy this need."); Ben-Shahar, supra note --, at 407 ("The precontractual commitment enables a party to commit to a specific partner and a specific negotiation protocol without committing to specific terms.")

${ }^{84}$ Gilson, Sabel and Scott, supra note --.
} 
stage, and deal participant - that weighs the marginal transactional flexibility [from the ability to walk away] and cost savings from reduced formalization against the marginal increased risk of holdup and other forms of counterparty opportunism". ${ }^{85}$

Practitioners, courts and scholars are all aware of the existence of non-legal sanctions that visit the party who unreasonably withdraws from negotiations or makes outlandish demands. Sometimes, these extralegal forces achieve the desirable combination of commitment and flexibility. For example, in his discussion of soft contracts between Hollywood movie studios and star actors, Jonathan Barnett reports that there are norms deterring the most egregious forms of hold-up that are available once a studio has begun filming with a star. He observes that "[i]n practice, nothing close to this extreme form of holdup behavior actually occurs: even in the absence of a signed deal, talent attorneys report that they renegotiate open terms following production but refrain from renegotiating the fixed compensation." 86 This is consistent with the good faith negotiations that are sometimes required in midstream commercial agreements which impede the renegotiation of settled terms but provide flexibility in the negotiation of open terms.

In other contexts, however, lawyers and scholars acknowledge that nonlegal sanctions do not completely deter such behavior and might need to be paired with some degree of legal enforcement. Scott Baker and Albert Choi observe that many extralegal sanctions impose costs on both the party that metes the sanction and the one that receives it. ${ }^{87}$ To impose a meaningful relational or reputational sanction, the enforcer must forego a profitable transaction or relationship with the transgressor, with a corresponding loss in surplus. In contrast, the outcome of legal enforcement is a payment (e.g. of reliance damages) between the parties, with some deadweight loss for litigation. The parties, ex ante, may prefer the latter system. In addition, in many contexts, the legal system is a reasonably effective producer of information about the conduct of the alleged bad actor, with access to different and sometimes superior information than the counterparty and to third parties in the reputational community. The fact finding of the courts may inform the discretion of these parties to impose non-legal sanctions.

The use of a standard - such as good faith or reasonable efforts - to police the negotiation process seems an appropriate mechanism for legal enforcement of midstream agreements. ${ }^{88} \mathrm{We}$ have identified several goals that the parties may seek to promote in regulating their negotiation process, beyond the protection of reasonable reliance investment. These require a highly contextual approach that befits a standard. Good faith and best efforts are familiar standards in contract and commercial law. However, lawyers and scholars are often critical of vague standards that call for fact-specific determinations because they introduce the costs of unpredictability, judicial error and litigation cost.

\footnotetext{
${ }^{85}$ Id., at 644.

${ }^{86}$ Barnett, supra note - at 641.

${ }^{87}$ Scott Baker and Albert Choi, Contracts Role in Relational Contract, 101 Va. L. Rev. 559 (2015).

${ }^{88}$ Omri Ben-Shahar focuses on incomplete agreements where the parties deliberately leave terms to be agreed upon later. Ben-Shahar, supra note --. Instead of having the court police the specific investments of the parties, he advances a novel proposal that the party seeking enforcement of a deliberately incomplete agreement would have an option to enforce the transaction under the agreed-upon terms supplemented by terms that are the most favorable (within reason) to the defendant. Ben-Shahar argues that this facilitates sequential negotiations and deters unilateral retractions or threats to precontractual investments. Id. At 392.
} 
Noting that contracting parties regularly agree to standards of conduct when more precise rules are available, we have addressed these concerns in other work. ${ }^{89}$ In brief, the costs of litigation and unbiased judicial error are, of course, avoided when parties settle their dispute, as they often do. Moreover, they can be mitigated and a more efficient incentive can be implemented, when the standards are combined with contract provisions that calibrate litigation costs and liquidated damages for breach to efficiently set both litigation and performance incentives.

To illustrate, suppose that a court will accurately determine whether a promisor has breached the standard, as intended by the parties, two-thirds of the time. One third of truly breaching promisors escape liability and one-third of truly non-breaching promisors are held liable. ${ }^{90}$ Suppose also that the parties know perfectly whether there has been a breach, and that damages are stipulated at an amount $d$ and the litigation cost for the plaintiff is $l$. By suing, a plaintiff invests $l$ for a lottery ticket that gives it a $2 / 3$ chance of winning $d$ if the promisor has truly breached and a $1 / 3$ chance of winning $d$ if the promisor has truly not breached. If $d$ is set so that $(2 / 3) d>l>(1 / 3) d$, the plaintiff will sue only when the promisor has truly breached. This is a fairly broad range and the parties can manipulate liquidated damages $d$ and litigation costs $l$ (by contracting over choice of forum or procedural rules, for example) to some degree. When this condition is satisfied, the sanction of $d$ provides an accurate deterrent to breach of the good faith or best efforts standard, as it was intended by the parties, even in the face of a substantial risk of judicial error. Thus, whether the parties adopt a negotiation standard of good faith or best efforts, the parties can realize the benefits of their contextual application while avoiding the downsides. ${ }^{91}$

Regulating negotiations with a standard such as good faith promotes the various objectives of the party. Returning to the goals of midstream agreements, if the parties wish to lock into a distribution of (expected) surplus (by allocating certain risks and deterring valueclaiming efforts) and encourage the building of surplus in efficient deal terms, they might call on a court to do so by applying a standard of good faith. They might also help the parties promote efficient investment in identifying optimal terms and preventing abuse of private information by the investing party. If one party proposes new terms and the other balks, and both sides accuse the other of opportunism or value-claiming, the truth will not be transparent in many cases. The foregoing argument suggests that even if the courts are error-prone, the litigation process as a whole may be designed to yield efficient enforcement and incentives. Furthermore, as we have argued in our earlier works, ${ }^{92}$ in designing the remedy ( $d$ from the example), the objective should not be compensation of the victim per se but creating the screening mechanism to produce more effective deterrence. The design of a standard that relies on costly screening of litigation is illustrated by the numerical example in the Appendix.

\section{Conclusion}

\footnotetext{
${ }^{89}$ Choi and Triantis, Costly Verification, supra note --; Choi and Triantis, Strategic Ambiguity, supra note --.

${ }^{90}$ The probability of $1 / 3$, therefore, captures both false positives (type I error) and false negatives (type II error).

${ }^{91}$ In this sense we are allied with Barnett, supra note --, who similarly sees virtue in probabilistic enforcement; but we endorse the use of a substantive standards in the terms (good faith, best efforts) rather than the uncertainty from incomplete formalization of the deal.

${ }^{92}$ Choi and Triantis, Costly Verification, supra note --; Choi and Triantis, Strategic Ambiguity, supra note --.
} 
In this paper, we have presented a function for midstream agreements in staged contracting that improves the efficiency of complex business transactions. Parties may use the midstream agreement to regulate their negotiations, by including terms such as the duty to negotiate in good faith or with best efforts and temporary exclusivity rights prohibiting competing negotiations with third parties. We envisage a scenario (by no means the only possible scenario of staged contracting) in which the parties have conducted enough of their search and diligence activities to be confident that they have found the right counterparties. At this point, they seek to deter value-claiming and encourage value-creating investments, where value-creation includes the discovery of optimal deal terms. They also often seek to efficiently allocate risks of changes in their circumstances. The terms provided in the midstream agreements must have some moderate degree of commitment in order to satisfy this set of goals, and we suggest that contract standards such as good faith and best efforts can provide desirable types of stickiness. In addition, we show how such standards can better address the hazard of information asymmetry, where one party has (or is perceived to have) an informational advantage over the counter party in recognizing the optimal deal terms. Good faith and best efforts obligations can (effectively) deter the party from abusing its informational advantage solely for the purpose of extracting a bigger rent from the other. 


\section{Appendix: A Numerical Example}

Using game theoretic analysis, this part shows how contracting parties can tackle the problems of asymmetric information and non-verifiability in achieving two, inter-related goals: efficient renegotiation of the initial agreement (ex post efficiency) and provision of necessary investment incentive (ex ante efficiency). The analysis will first show that if the parties are symmetrically informed of each other's actions or the court can easily verify them, the contracting parties can achieve the efficient solution regardless of the underlying legal regime, i.e., whether the midstream agreement is binding, non-binding, or non-binding but with duty to negotiate in good faith. By contrast, when the problems of information asymmetry and nonverifiability are present, the legal status of the midstream agreement matters. The analysis shows that a fully binding midstream agreement will be unable to check the informed party's rent extraction behavior that prevents the parties from achieving efficient renegotiation and investment. While a non-binding midstream agreement will do better, the duty to negotiate in good faith can often best police the informed party's opportunism.

\section{A. The Setup}

Let's start with a brief overview. Two parties, B and S, are negotiating over a transaction. We will adopt the project or product development analogy, where $S$ (as the project or the product "seller") develops and delivers the product and B (as the project or the product "buyer") pays for the product and funds the development. The buyer can also engage in other, down-stream activities, such as marketing and sales, but for simplicity, we will assume those away and focus on the seller's behavior. For instance, the seller could be a bio-tech company, such as SIGA, that develops a new drug for a larger pharmaceutical company, such as PharmAthene, which will fund the development and also market and sell the developed drug. The analogy can be extended to other settings, such as a manufacturer developing a new smartphone for a wireless carrier, a property developer constructing a new commercial property for a purchaser, or a seller transferring assets to a buyer in return for a purchase price.

The interaction takes place over five periods and, for convenience, there is no time discounting. In the first period $(t=1)$, the buyer and the seller enter into an midstream (initial) agreement that stipulates the product to be developed by the seller and the payment to be made by the buyer once the product is delivered. In the second period $(t=2)$, the seller can make a project-specific or relationship-specific investment, that can increase the value of the product for the buyer and also lower the production cost for the seller. To focus on the investment that is relationship-specific, we will "normalize" all other investment costs to be zero. Whether or not the seller has made the investment and the seller's production cost are not observable to the buyer. Similarly, the buyer will not be able to observe the value of the product until the product has been delivered. As we will see, the assumption that the seller's investment is unobservable to the buyer and the seller's knowledge is private information will function as an obstacle against efficient investment and trade.

In the third period $(t=3)$, the parties attempt to renegotiate or modify the initial agreement. This is where the seller will—utilizing her informational advantage — attempt to get 
a higher price with the allegation that her investment in the previous period has increased the value for the buyer (and lowered the production cost). In the fourth period $(t=4)$, if a binding agreement has been entered into in the previous period $(t=3)$, the seller produces and delivers the product. In the final period $(t=5)$, the buyer's value is realized (e.g., through resale) and, depending on the legal regime that governs the midstream agreement, the buyer may be able to bring suit against the seller in case the buyer is dissatisfied with the product. We will assume that the court cannot verify the value or the cost of the product but the court can verify whether the stipulated product has been delivered and whether the payment has been made. We will later assume that the court will also be able to determine, at cost and with some error, whether the parties acted in "good faith" when they were renegotiating the initial agreement.

\section{Contractual Surplus and Seller's Investment}

Depending on whether the seller makes the project-specific investment at $t=2$, developed product's value to the buyer and cost to the seller differ. We will assume that there are different types of product that the seller can develop. First, there is a "standard product" with generic features that is worth $\$ 200$ to the buyer and costs $\$ 100$ for the seller to produce, thereby generating a surplus of $\$ 100$ for the pair. Instead of the standard product, the seller can add other features (or attributes) and develop a "special product." For instance, for a pharmaceutical drug, the features could include minimizing certain side-effects, changing the delivery method, allowing the drug to treat other symptoms, and others. If the seller is developing a new smartphone for the buyer, additional features can range from sharper display to faster processor to longer battery life and so on. Unless the seller has made the project-specific investment, we will assume that a special product will cost more for the seller to produce but will not add any value to the buyer: it's worth $\$ 200$ to the buyer but costs $\$ 150$ for the seller. For instance, a new drug that eliminates a certain side-effect may really not be worth additional value to the pharmaceutical buyer, perhaps because the patients who would use that drug would rarely be vulnerable to the side-effect. Or, a sharper display for a smartphone may be worth little for the buyer because the phone has limited processing capacity. We will call this "unmatched special product." With only $\$ 50$ of surplus, an unmatched special product generates a strictly lower surplus compared to the standard product.

However, the seller can make a $\$ 40$ of project-specific investment that will identify a specific feature (or attribute) that will generate additional surplus. We can think of the seller's investment to consist of investigating the buyer's specific needs, identifying which additional feature will satisfy those needs, and lowering the cost of production for the development project. For instance, improving the delivery method for the new pharmaceutical drug may be more important than eliminating certain side-effects. For a new smartphone, the buyer may benefit more from a longer battery life than a sharper display. We will call this the "matched special product" and this product is worth $\$ 300$ for the buyer and costs the seller $\$ 120$ to produce and deliver. Compared to either the standard product or the unmatched special product, the matched special product generates the largest gross surplus for the pair $(\$ 180)$ but identifying the tailored product requires $\$ 40$ of investment from the seller. (As stated before, apart from the $\$ 40$ of project-specific investment, we will normalize other developments cost to be zero.) The following table summarizes the parameters depending upon product's features. 


\begin{tabular}{|c|c|c|c|}
\hline & $\begin{array}{c}\text { Product with Generic } \\
\text { Features (Standard } \\
\text { Product) }\end{array}$ & $\begin{array}{c}\text { Product with Random } \\
\text { Additional Feature } \\
\text { (Unmatched Special } \\
\text { Product) }\end{array}$ & $\begin{array}{c}\text { Product with } \\
\text { Matched Additional } \\
\text { Feature (Matched } \\
\text { Special Product) }\end{array}$ \\
\hline Buyer's Value & $\$ 200$ & $\$ 200$ & $\$ 300$ \\
\hline Seller's Cost & $\$ 100$ & $\$ 150$ & $\$ 120$ \\
\hline Gross Surplus & $\$ 100$ & $\$ 50$ & $\$ 180$ \\
\hline
\end{tabular}

Table 1: Buyer's Value and Seller's Cost Depending on Product (Service) Type

As Table 1 shows, it is efficient for the parties to develop the standard product if the seller has not made the project-specific investment, whereas the parties should develop the matched special product if the seller has made the $\$ 40$ investment. Without the investment, producing an unmatched special product (with some random additional features) will generate only $\$ 50$ of surplus. If the parties were to develop the standard product, on the other hand, they will realize a (gross and net) surplus of $\$ 100$. If the seller has made the $\$ 40$ investment, identified the buyer's specific needs, and lowered the production cost, by developing the matched special product, they get to realize the gross surplus of $\$ 180$. Even with the $\$ 40$ of investment cost, the net surplus is $\$ 140$, which is strictly higher than the net surplus from developing the standard product. Furthermore, given that the $\$ 40$ investment will increase the gross surplus from $\$ 100$ to $\$ 180$, it is efficient for the seller to make the investment and to increase the net surplus. ${ }^{93}$

As briefly mentioned before, however, whether the seller has actually made the projectspecific investment is unobservable to the buyer. Also, while the buyer does observe whether the product comes with additional features, the buyer does not get to observe or appreciate the value of the product until the product has been delivered to and used by the buyer. ${ }^{94}$ At the time of renegotiation (at $t=3$ ), only the seller knows whether she has made the $\$ 40$ investment (at $t=2$ ) and identified the value-enhancing attributes (the "matched special product"). The seller has an informational advantage at the time of the renegotiation and, as we will see, will attempt to leverage this advantage to extract more value from the buyer. Furthermore, as is conventional in the literature, we assume that the court also cannot verify the investment, value to the buyer, or the cost to the seller. This implies that the parties cannot write a contract that is contingent upon the realized value or cost. ${ }^{95}$ The court can, on the other hand, verify whether the promised product (e.g., drug with different delivery method) has been delivered by the seller and whether the promised payment has been made by the buyer.

\section{Negotiation and Contracting Process}

Now, let's turn to the negotiation process and description of different legal regimes. Foremost, the parties execute an midstream (initial) agreement to trade the standard product at

\footnotetext{
${ }^{93}$ We can generalize this by making the increase in net surplus probabilistic: by increasing the probability of finding the right match when the seller makes the investment.

${ }^{94}$ In the economics literature, this is sometimes called an "experience good" that the purchaser must first use (or "experience") before recognizing the product's worth. Because of the delay in value recognition, experience goods can create seller opportunism as is the case in our example.

${ }^{95}$ Without this assumption, the private information problem can be easily solved by writing a value-contingent (or cost-contingent) contract.
} 
$t=1$. The midstream agreement can be of three types: (1) non-binding; (2) fully binding; and (3) non-binding but with the duty to negotiate in good faith. If the midstream agreement is nonbinding, unless the parties execute a binding agreement at $t=3$, either party can simply walk away from the transaction without any legal consequences. On the other hand, if the midstream agreement is fully binding, walking away from the deal (at $t=3$ ) constitutes breach, entitling the victim to recover damages from the breaching party. ${ }^{96}$ Finally, if the initial agreement is non-binding but imposes a duty to negotiate in good faith, the parties do not have an obligation to execute a binding agreement (at $t=3$ ) but do have an obligation to act in good faith with each other. We will later be more precise about what this duty entails. To keep the bargaining protocol as simple as possible, we will assume that with respect to both the initial negotiation $(t=1)$ and the terminal negotiation $(t=3)$, the seller gets to make a single take-it-or-leave-it offer to the buyer and the buyer gets to either accept or reject the offer. ${ }^{97}$

\section{B. The First Best and Symmetric Information Benchmark}

As presented before, it is efficient for the seller to develop and sell the standard product if the seller has not made the project-specific investment and to sell the matched special product if the seller has made the investment. Also, because the $\$ 40$ investment increases the gross surplus by $\$ 80$, it is efficient for the seller to make the investment and find the right match for the buyer and lower the production cost. If the relationship is not plagued by the problems of unobservability (of the seller's investment) and asymmetric information (over the seller's investment, buyer's value, and the seller's cost), the parties will be able to achieve the efficient outcome even with the weak legal enforcement regime, where the court can verify only the product attributes and payment but not the values and costs. Furthermore, as we will see shortly, the legal status of the midstream agreement will not matter. That is, whether the midstream agreement is binding, non-binding, or non-binding but with duty to negotiate in good faith, the parties will be able to achieve the efficient outcome.

To see this, suppose, at $t=1$, the seller, with her power to make a take-it-or-leave-it offer, offers to develop and deliver the standard product at a price of (slightly less than) \$200. ${ }^{98}$ Since the buyer is willing to pay up to $\$ 200$ for the product, the buyer will accept the offer. Skipping the seller's investment choice for the moment, suppose at $t=3$, both the buyer and the seller know whether the seller has made the investment in $t=2$ and both are aware of the identity of the matched special product. ${ }^{99}$ If the seller had made the investment, the seller will make a new offer of (slightly less than) $\$ 300$ for the matched special product. The buyer would accept the modified offer, knowing that the matched special product will generate a value of

\footnotetext{
${ }^{96}$ At the moment, it does not really matter how this promise will be enforced, but, for ease of exposition, we will assume through specific performance.

${ }^{97}$ Allowing the seller to make a take-it-or-leave-it offer makes the seller the "residual claimant" for the contractual surplus and makes it easier for the parties to implement the more efficient outcome. Also, in the case of asymmetric information, the seller is able to "signal" her private information to the buyer through the offer.

${ }^{98}$ We will often carry the phrase "slightly less than," but for analytical simplicity, we will skip the phrase while keeping the price equal to the maximum value that the buyer is willing to pay (buyer's reservation value).

${ }^{99}$ In game theory parlance, the seller's investment choice is "common knowledge" among the buyer and the seller. This means that not only is the buyer aware of whether the seller made the investment, but the seller knows that the buyer knows, and so on.
} 
$\$ 300$ for her. ${ }^{100}$ If the seller did not make the investment, the parties will simply affirm the initial agreement to trade the standard product at $\$ 200$. If the seller, who did not make the investment at $t=2$, were to make the $\$ 300$ offer to the buyer with some random additional attribute ("unmatched special product"), the buyer will simply reject the offer since the buyer knows that the unmatched special product will generate only $\$ 200$ of value for her.

Expecting the renegotiation outcome in $t=3$, the seller's investment choice at $t=2$ becomes clear. She knows that, if she were to make the $\$ 40$ investment, she will be able to sell the matched special product to the buyer at $\$ 300$ at a production cost of $\$ 120$. If she were to skip on the investment, she will sell the standard product at $\$ 200$ at $\$ 100$ production cost. Making the $\$ 40$ investment and increasing the gross profit to $\$ 180$ from $\$ 100$ is clearly in the seller's interest. Even with the $\$ 40$ investment, the net profit will rise from $\$ 100$ to $\$ 140$. The example, therefore, demonstrates that, without the problems of unobservability and asymmetric information, the parties can achieve the efficient outcome. Whether the initial agreement is binding, non-binding, or non-binding with the duty to negotiate in good faith, the parties are able to implement the ex post efficient outcome, i.e., trading standard product without investment and matched special product with investment. Furthermore, the seller is given the proper investment incentive. From the example, if the cost of investment were more than $\$ 80$, for instance, the seller will not make that investment and that would also be efficient.

\section{Problems of Renegotiation under Asymmetric Information}

Coming back to the original assumptions, when the seller's investment choice is unobservable and the other relevant parameters (values and costs) are private information to the seller, it will be much more difficult for the parties to achieve an efficient renegotiation and also provide proper investment incentive to the seller. The source of the problem is the seller's opportunism. Even if the seller has not made the investment and knows that there is no additional surplus from the transaction, relying on the fact that the buyer is not aware of this, the seller would be tempted to utilize that informational leverage to extract more surplus from the buyer. The buyer, in turn, becomes skeptical of the seller's claims and unwilling to accept any renegotiation offer. In tackling such opportunism, whether the midstream agreement is binding, non-binding, or non-binding but imposes the duty to negotiate in good faith, will now matter. We will examine these three legal regimes in turn.

\section{When the Midstream Agreement Is Binding}

Let's start with the case where the midstream agreement that the parties enter into (at $t=$ 1 ) is binding: the initial agreement is a contract. Suppose, as before, at $t=1$, the seller offers to develop and deliver a standard product to the buyer at a price of (slightly less than) \$200. Given that the buyer would be willing to pay $\$ 200$ for the product, the buyer would again accept the offer and the parties will have a binding agreement. Because the agreement is binding, unless they modify the contract at $t=3$, the seller will have an obligation to deliver, and the buyer will have an obligation to accept and pay for, the standard product. ${ }^{101}$ With the price of $\$ 200$ and the production cost of $\$ 100$, the agreement will also guarantee a profit of $\$ 100(=\$ 200-\$ 100)$ for

\footnotetext{
${ }^{100}$ If the initial agreement had a price of $\$ 199.99$, the modified offer can, for instance, come with a price of $\$ 299.98$.

${ }^{101}$ Again, for ease of exposition, we will assume that the court will enforce this contract using specific performance.
} 
the seller. Although having a binding initial agreement will guarantee that the parties will transact and will at least realize a $\$ 100$ of surplus, the fact that the seller is guaranteed to capture a positive profit implies that the parties will face a particularly difficult challenge of modifying the contract to implement the efficient terms at $t=3$.

To see this, let's again skip the seller's investment choice for the moment, and focus first on the parties' modification challenge at $t=3$. From the buyer's perspective, given that the buyer does not know whether the seller made the investment in the previous period, the buyer is likely facing two different "types" of seller. If the seller made the investment at $t=2$, the buyer would be willing to pay up to $\$ 300$ for the matched special product. We will call this seller the "high" type seller. If, on the other hand, the seller did not make the investment, the buyer would be willing to pay up to $\$ 200$ for the standard product (or for any unmatched special product). We will designate this seller as "low" type seller. With respect to the high-type seller, the buyer would be willing to modify the price up to $\$ 300$ (and add features to the product that will produce value) while with the low-type seller, the buyer would be unwilling to increase the price. The problem, of course, is that the buyer does not know which type of seller she is facing and this makes successful modification difficult. The buyer needs to make an inference based on each type's incentive in making different offers.

With the assumption that the seller is making the take-it-or-leave-it modification offer to the buyer, suppose the high-type seller were to make a modification offer, consisting of the new price of (slightly less than) $\$ 300$ and (matched) additional features. Suppose the buyer accepts this modification offer. The buyer, of course, does not know that the specific attributes offered by the seller is value increasing but is willing to trust the seller's claim. If the low-type seller were aware of this, will the low-type seller be content with providing the standard widget at \$200? The answer is no. The low-type seller will have a strong incentive to "mimic" the hightype seller and also offer the modified price of $\$ 300$ (with random additional features), alleging that the seller made the investment in the previous period and is offering a matched special product. Given that the court cannot verify the realized value for the buyer and that the buyer has no legal recourse against the seller, ${ }^{102}$ the low-type seller will have an incentive to mimic the high-type by making the same modification offer. Of course, if the buyer is aware of the lowtype seller's incentive, the buyer will no longer accept the $\$ 300$ modification offer and renegotiation will fail.

What if the buyer were to accept the modification offer with less than certainty, say with only $50 \%$ probability? Unfortunately, even with the lower probability, the low-type seller will still have an incentive to mimic the high-type. By mimicking the high-type by offering $\$ 300$, the low-type seller has a chance to realize an expected profit of $\$ 125(=(0.5) \times(\$ 300-\$ 150)+$ $(0.5) \times(\$ 200-\$ 100))$, which is strictly larger than the $\$ 100$ profit she would earn by producing and delivering the standard widget. In fact, so long as there is a positive probability of the buyer accepting the modified offer of $\$ 300$, the low-type seller will mimic the high-type. ${ }^{103}$

\footnotetext{
${ }^{102}$ We will briefly mention the contracting parties' duty to exercise good faith in modifying the contract after discussing the good faith duty in the last section.

${ }^{103}$ To see this, suppose the buyer accepts the $\$ 300$ modification offer with probability $\alpha$. The low-type seller's expected profit by mimicking the high-type is given by: $\alpha \times(\$ 300-\$ 150)+(1-\alpha) \times(\$ 200-\$ 100)$. Note that $\alpha \times(\$ 300-\$ 150)+(1-\alpha) \times(\$ 200-\$ 100)$ whenever $\alpha>0$.
} 
The buyer, rationally expecting this, will reject all modification offers from the seller and always stick with the initial standard widget. The seller, in turn, expecting that the buyer will reject all modification offers at $t=3$, will have no incentive to incur the $\$ 40$ investment (at $t=2$ ) to find the right match for the buyer. In equilibrium, the seller does not make the investment and will always develop and deliver the standard product.

Why is it impossible for the parties to efficiently modify the contract and to provide the necessary investment incentive to the seller when the initial agreement is binding? The problem is due largely to the fact that the binding initial agreement guarantees a minimum profit for the seller, in particular, the low-type seller. Because the low-type seller knows that she will be able to develop and deliver the standard product and realize a profit of $\$ 100$ even if the buyer were to reject the modification offer, the low-type seller has nothing to lose by opportunistically offering to modify the contract to the price of $\$ 300$ (and adding some random additional attributes). Whenever the modified contract generates a larger profit - which is necessary to provide the seller with costly investment incentive, the low-type seller will always mimic the high-type. ${ }^{104}$ The rationally expecting buyer will be unwilling to accept any modification offer that produces a bigger profit for the seller, and this, in turn, will eliminate any investment incentive for the seller.

\section{When the Midstream Agreement Is Non-Binding}

If the initial agreement is non-binding, the parties are better able to realize the additional surplus but still at an insufficient level. Similar to the previous case, suppose the buyer and the seller initially (at $t=1$ ) agree to trade the standard widget at (slightly less than) $\$ 200$. But, now, the agreement is non-binding. That is, unless the parties execute a binding agreement at $t=3$, neither party will have a contractual obligation. ${ }^{105}$ Skipping the investment stage $(t=2)$ for the moment, suppose that the high-type seller were to make a contract offer at $t=3$, consisting of a price of (slightly less than) $\$ 300$ and the product with additional, value-enhancing attributes (matched special product). If the buyer were to accept this offer for certain, we will be back to the previous problem of granting too much incentive to the low-type seller to mimic the hightype type. Hence, the buyer always accepting this offer is out of the question. Is there any way we can achieve a separation between the high-type and the low-type seller?

It turns out, unlike the case of binding initial agreement, if the buyer were to reject the renegotiation offer (consisting of $\$ 300$ price) with probability (slightly higher than) $1 / 3$, the low-type seller will no longer have an incentive to mimic the high-type. To see this, if the lowtype seller were to stick with the standard widget and the $\$ 200$ price, the low-type seller will earn a profit of $\$ 100$. If, on the other hand, the low-type seller were to mimic the high-type seller and make an offer of $\$ 300$ (and adding some random additional attributes to the product), with probability $1 / 3$, the seller will realize a zero profit while, with probability $2 / 3$, the seller will realize a profit of $\$ 150(=(\$ 300-\$ 150))$. The expected profit from mimicking the high-type type, therefore, is (slightly less than) $\$ 100(=(2 / 3) \times \$ 150)$. So long as the buyer's rejection probability is slightly higher than $1 / 3$, the low-type seller is better off sticking with (or reaffirming) the initial agreement to produce and deliver the standard product. The high-type

\footnotetext{
${ }^{104}$ In game theory parlance, the only possible equilibrium here is a "pooling" equilibrium where both types of seller will behave the same way, i.e., make the same modification offer.

${ }^{105}$ We can think of this initial agreement as a non-binding preliminary negotiation.
} 
seller, on the other hand, is willing to make the offer of $\$ 300$ (with the matched special product). With 2/3 acceptance probability, the high-type seller will realize a profit of $\$ 120(=(2 / 3) \times$ $(\$ 300-\$ 120)$ ). If the high-type seller were to stick with the standard widget, the high-type seller will capture a profit of $\$ 100(=\$ 200-\$ 100)$. Clearly, the high-type seller is better off making the new offer of $\$ 300$ and the two types of seller will separate.

At the same time, however, although the seller types are separated (in terms of the renegotiation behavior) because the buyer is rejecting the new offer with too high a probability and the high-type seller is getting insufficient profit, the seller will have an insufficient investment incentive. As of $t=2$, the seller knows that if she were to make the $\$ 40$ investment, she will expect a profit of $\$ 120$ by offering a new price of $\$ 300$ (with matched special product) at $t=3$, while if she were to not make the investment, she will realize a profit of $\$ 100$. The additional profit of $\$ 20$ is insufficient for the seller to spend $\$ 40$ in identifying the special attributes and lowering the cost. Notwithstanding the chance of earning an additional \$20 in profit, the seller will forego making the investment and, in equilibrium, the parties will always trade the standard widget. If the investment cost were $\$ 15$, instead of $\$ 40$, for instance, the additional \$20 would have been sufficient to solve the investment problem. ${ }^{106}$ The parties will still not be able to fully utilize the seller's investment, since, after the investment, with $1 / 3$ probability, the parties will not trade.

Compared to the previous regime of binding midstream agreement, the parties are able to at least partially alleviate the problems of asymmetric information and un-observability. The reason why a non-binding midstream agreement does better is that the seller is no longer guaranteed of realizing a positive profit in case the renegotiation fails. When the midstream agreement was binding, the low-type seller had nothing to lose by mimicking the high-type since, even when the modification offer was rejected by the buyer, the low-type seller could fall back to the initial, binding agreement that generated a $\$ 100$ of profit. When the midstream agreement is not binding, however, the buyer's rejection of the renegotiation offer by the seller meant that there is no trade and the seller is unable to realize any profit. There is a bigger downside for the low-type seller in mimicking the high-type. This didn't fully solve the problem, however, since the parties do not always trade (ex post inefficiency) and there was insufficient investment incentive (ex ante inefficiency). We now turn to the third legal regime, where the midstream agreement is non-binding but imposes the duty to negotiate in good faith.

\section{Duty to Negotiate in Good Faith}

We have to first start with a discussion on what the duty to negotiate in good faith means and how that can be applied in our setting. Although the conception of "good faith" obligation varies depending on the context, courts and the statutes have generally recognized two important elements in the duty: honesty in fact and fair dealing. ${ }^{107}$ That is, contracting parties must be honest on relevant facts, and must deal fairly, with each other. In our setting, the requirement of honesty in fact and fair dealing can be especially useful in curbing the low-type seller's behavior.

\footnotetext{
${ }^{106}$ By contrast, when the initial agreement was binding, because both the high-type and the low-type were always pooling, the seller was unable to generate any positive profit from the investment. The seller was unwilling to undertake any costly investment.

${ }^{107}$ See, for instance, the definition of "good faith" in the Uniform Commercial Code §1-201(20).
} 
When the low-type seller is mimicking the high-type, the seller is both being dishonest in fact (by claiming that the seller made the investment and has discovered the matching, valueenhancing attributes) and dealing unfairly with the buyer (by making a modification offer to substantially increase the price from $\$ 200$ to $\$ 300$ even though the buyer will not value the new product as much). By contrast, when the high-type seller makes the modification offer (or when the low-type seller is sticking with the standard product), we can think of the seller as being both honest in fact (by disclosing the value-enhancing attributes to the buyer) and dealing fairly (by increasing the price by the amount the buyer would be willing to pay for).

In terms of liability, although the court is unable to verify the realized costs and value, we will assume that the court may be able to observe the negotiation (renegotiation) process, by analyzing the contextual evidence surrounding the negotiation, to determine (with error) whether the seller has breached the duty to negotiate in good faith. Also, resorting to adjudication is assumed to be costly for both parties. To make this more concrete, suppose the court correctly determines the seller's negotiation behavior with $2 / 3$ probability. That is, if the low-type seller mimicked the high-type, the court finds the seller liable with $2 / 3$ probability while exonerating the seller with $1 / 3$ probability. Similarly, if the buyer were to bring suit against the high-type seller, the court will find that the seller satisfied the duty with $2 / 3$ probability while incorrectly finding the seller liable with $1 / 3$ probability. ${ }^{108}$ In terms of litigation cost, let's assume that prosecuting and defending the duty of good faith claim costs each party $\$ 50$.

\begin{tabular}{|c|c|c|}
\hline & $\begin{array}{c}\text { Low-Type Seller Offers \$300 } \\
\text { and Unmatched Special } \\
\text { Product }\end{array}$ & $\begin{array}{c}\text { Low-Type Seller Offers \$200 } \\
\text { and Standard Product }\end{array}$ \\
\hline $\begin{array}{c}\text { Breach of Duty to Negotiate } \\
\text { in Good Faith }\end{array}$ & $2 / 3$ & $1 / 3$ \\
\hline $\begin{array}{c}\text { No Breach of Duty to } \\
\text { Negotiate in Good Faith }\end{array}$ & $1 / 3$ & $2 / 3$ \\
\hline
\end{tabular}

Table 2: Court Accuracy in Application of Duty to Negotiate in Good Faith

To close the loop on the litigation process, suppose the initial agreement is non-binding but imposes the duty to negotiate in good faith. ${ }^{109}$ With the seller getting to make a take-it-orleave-it offer, the buyer is the one who will prosecute the claim. Suppose, at $t=5$, the buyer can bring a breach of good faith suit against the seller after the negotiation fails at $t=3{ }^{110}$ By now, the buyer has learned the values and can tell whether the low-type seller attempted to extract rent from her by mimicking the high-type at $t=3$. Suppose the damages (for breaching the duty of good faith) are set at (slightly less than) $\$ 150(D=\$ 150)$. With the litigation cost of

\footnotetext{
${ }^{108}$ In statistical terms, the $1 / 3$ probability stands for both "false positives" (finding the high-type seller liable) and "false negatives" (finding the low-type seller not liable). We impose this symmetry for ease of exposition.

${ }^{109}$ Alternatively, we can assume that the initial agreement is binding and the parties have an obligation to modify the agreement only in good faith. In fact, this is the regime adopted by the Uniform Commercial Code, see UCC $\$ 2-$ 209. As we show elsewhere, though, because the seller still has the downside protection of earning $\$ 100$ of profit in case the modification fails, achieving separation between the types and providing sufficient investment incentive to the seller is more difficult.

${ }^{110}$ We can alternatively assume that the buyer will bring suit against the low-type seller after the buyer accepts the low-type seller's mimicking offer and the low-type seller has delivered a non-conforming good. Either assumption will produce qualitatively the same result.
} 
$\$ 50$, the damages are sufficiently large for the buyer to bring suit against the low-type seller when the low-type seller made a mimicking offer of $\$ 300$. To see this, because the court will find the low-type seller liable with $2 / 3$ probability, the buyer expects to recover from litigation, net of litigation cost, $\$ 50(=(2 / 3) \times(\$ 150)-\$ 50)$. On the other hand, the buyer will not bring suit against either the high-type seller or the low-type seller who was truthful since, with only $1 / 3$ probability of success and damages of (slightly less than) $\$ 150$, the expected return from litigation is negative: $(1 / 3) \times(\$ 150)-\$ 50=\$ 0$. Hence, with the $\$ 50$ litigation cost, $\$ 150$ of damages are large enough to provide desirable screening of lawsuits. ${ }^{111}$

Turning to the seller, once the low-type seller faces the possibility of facing the breach of good faith duty lawsuit, it becomes much less attractive for her to mimic the high-type. If she were to mimic the high-type and offer $\$ 300$ and the buyer were to reject that offer at $t=3$, she knows that the buyer will bring suit at $t=5$ and she will expect to lose, from litigation, $\$ 150$ (= $(2 / 3) \times(\$ 150)+\$ 50)$. At the same time, she knows that when she is honest with the buyer and offers the standard product at $t=3$, she will be able to realize a profit of $\$ 100$. She also knows that she will not face a lawsuit from the buyer at $t=5$. Given the added deterrence effect, the buyer now needs to reject the $\$ 300$ offer with only (slightly higher than) 1/6 probability, rather than $1 / 3$ probability when the non-binding initial agreement did not impose a duty to negotiate in good faith. For the low-type seller, if she were to mimic the high-type, she expects to realize a profit of (slightly less than) $\$ 100$. To see this, when her mimicking offer is accepted with $5 / 6$ probability, she realizes a profit of $\$ 150$. But, when her offer is rejected with $1 / 6$ chance, she expects to lose $\$ 150$ from breach of good faith duty lawsuit. Combining the two, her expected return is (slightly less than) $\$ 100(=(5 / 6) \times(\$ 300-\$ 150)-(1 / 6) \times$ $(\$ 150)$ ). Hence, with $1 / 6$ rejection probability, the low-type seller will stick with the standard widget.

For the high-type seller, offering $\$ 300$ (with the matched special product) has become even more attractive than before. With 5/6 acceptance probability, if she were to make the $\$ 300$ offer (with matching special product), her expected return becomes $\$ 150(=(5 / 6) \times(\$ 180))$. She also knows that she will not face suit from the buyer since, with only $1 / 3$ probability of litigation success, $\$ 50$ litigation cost, and slightly less than $\$ 150$ of damages, the buyer's expected return from litigation is negative: $(1 / 3) \times(\$ 150)-\$ 50=\$ 0$. Hence, the high-type seller will offer $\$ 300$ and realize an expected profit of $\$ 150$. Finally, compared to the other two legal regimes, we have solved the investment problem. As of $t=2$, the seller knows that if she were to make the investment, she will earn an expected profit of $\$ 150$ (by selling the matched special product), whereas, without the investment, she will earn a profit of $\$ 100$ (by selling the standard product). The additional $\$ 50$ of profit is sufficient to cover the $\$ 40$ of investment.

\footnotetext{
${ }^{111}$ With $\$ 50$ of litigation cost and 2/3 court accuracy, so long as the damages are between $\$ 75$ and $\$ 150$, the buyer will bring suit only against the mimicking low-type seller.
} 


\begin{tabular}{|c|c|c|c|}
\hline & $\begin{array}{c}\text { Buyer's Probability } \\
\text { of Accepting \$300 } \\
\text { Offer }\end{array}$ & Seller Invests? & Expected Welfare \\
\hline $\begin{array}{c}\text { Binding Initial } \\
\text { Agreement }\end{array}$ & 0 & No & $\$ 100$ \\
\hline $\begin{array}{c}\text { Non-Binding Initial } \\
\text { Agreement }\end{array}$ & $2 / 3$ & No & $\$ 100$ \\
\hline $\begin{array}{c}\text { Non-Binding Initial } \\
\text { Agreement with Duty } \\
\text { of Good Faith }\end{array}$ & $5 / 6$ & Yes & $\begin{array}{c}\$ 110(=(5 / 6) \times \\
(\$ 180)-\$ 40)\end{array}$ \\
\hline
\end{tabular}

Table 3: Welfare Comparisons across Three Legal Regimes

Table 3 summarizes the equilibrium results and welfare comparisons across the three different legal regimes. When the initial agreement is binding, because the seller is guaranteed to have a positive profit in case modification efforts fail, the low-type seller will always mimic the high-type and the parties are unable to separate the two types. This, in turn, eliminates the seller's investment incentive. When the initial agreement is non-binding, achieving separation and renegotiating the initial agreement becomes much easier since the failure of renegotiation means that the seller realizes zero profit. The easier separation also provides a stronger investment incentive to the seller, but, given our parameter, the incentive still ends up being insufficient. When we have the non-binding agreement but with the duty to negotiate in good faith, the low-type seller's opportunism is even better deterred. This not only allows the parties to better renegotiate the deal (when there was more value to be claimed) but this also provides a strongest investment incentive to the seller. Although litigating the duty of good faith issue is subject to cost and possible court error, so long as the damages are calibrated at the right level, the parties are able to move frivolous lawsuits off the equilibrium and minimize (or eliminate) the expected cost of litigation. 